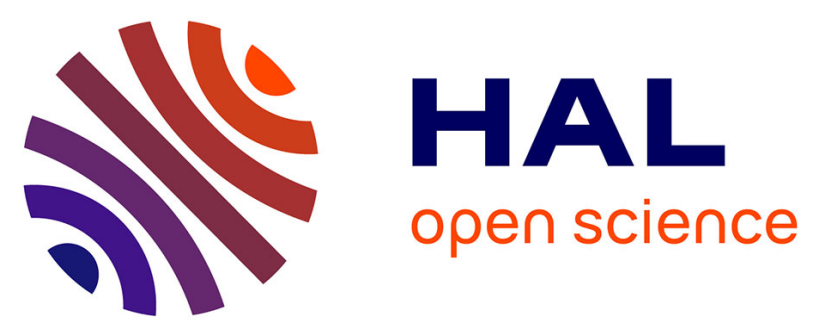

\title{
X-ray fluorescence microchemical analysis and autoradiography applied to cave deposits: speleothems, detrital rhythmites, ice and prehistoric paintings
}

Grégory Dandurand, Richard Maire, Richard Ortega, Guillaume Devès, Benjamin Lans, Laurent Morel, Anne-Sophie Perroux, Nathalie Vanara, Laurent Bruxelles, Stéphane Jaillet, et al.

\section{To cite this version:}

Grégory Dandurand, Richard Maire, Richard Ortega, Guillaume Devès, Benjamin Lans, et al.. Xray fluorescence microchemical analysis and autoradiography applied to cave deposits: speleothems, detrital rhythmites, ice and prehistoric paintings. Géomorphologie: relief, processus, environnement, 2011, 17 (4), pp.407-426. 10.4000/geomorphologie.9623 . hal-02017682

\section{HAL Id: hal-02017682 \\ https://hal-univ-tlse2.archives-ouvertes.fr/hal-02017682}

Submitted on 22 Nov 2019

HAL is a multi-disciplinary open access archive for the deposit and dissemination of scientific research documents, whether they are published or not. The documents may come from teaching and research institutions in France or abroad, or from public or private research centers.
L'archive ouverte pluridisciplinaire HAL, est destinée au dépôt et à la diffusion de documents scientifiques de niveau recherche, publiés ou non, émanant des établissements d'enseignement et de recherche français ou étrangers, des laboratoires publics ou privés. 


\title{
X-ray fluorescence microchemical analysis and autoradiography applied to cave deposits: speleothems, detrital rhythmites, ice and prehistoric paintings
}

\section{Analyses microchimiques par fluorescence $X$ et autoradiographie appliquées aux dépôts de grotte : spéléothèmes, rythmites détritiques, glace et peintures rupestres}

\author{
Grégory Dandurand*, Richard Maire*, Richard Ortega**, Guillaume Devès**, Benjamin Lans*, \\ Laurent Morel***, Anne-Sophie Perroux*, Nathalie Vanara*,****, Laurent Bruxelles*****, \\ Stéphane Jaillet******, Isabelle Billy*******, Philippe Martinez*******, \\ Bassam Ghaleb********, François Valla*********
}

\begin{abstract}
This article presents recent research on the sedimentary endokarstic infillings in connection with the new contributions of geochemical analysis by autoradiography and X-ray fluorescence (portable analyser, core scanner, micro-XRF, microprobe) in the context of the 'Climanthrope' ANR programme. Coupled with sedimentological analysis (stratigraphy, laser grain size analysis, micromineralogy, and micromorphology), geochemical analysis and imaging refine the study of underground deposits such as carbonated sediments (speleothems), rhythmites, subterranean ice, and prehistoric cave paintings. Formed following a seasonal cycle, stalagmites and rhythmites are likely to provide important data not only on the two main parameters of regional climate, i.e. hydrology and temperature, but also on human impacts (speleothems in urban tunnels) and the rural environment. The microdebris and dusts sampled in subterranean ice record the palaeoenvironment by snow trapping. Parietal paintings can be studied directly with a portable XRF analyser without sampling. In every case, the notion of the 'site effect' is discussed for four French examples (Pyrenees, Aquitaine, Charente, Rhône) and three foreign examples (Italy, Chile, China).
\end{abstract}

Key words: geochemistry, cave deposits, chemical imaging, autoradiography, micro-XRF, XRF core scanner, microprobe, sedimentology, site effect, human impact.

\section{Résumé}

Cet article présente les recherches récentes conduites dans le cadre du programme ANR «Climanthrope » et portant sur les remplissages sédimentaires endokarstiques dans le cadre de la nouvelle contribution de l'analyse géochimique par autoradiographie et fluorescence de rayons $X$ (analyseur portable, core scanner, $\mu-X R F$, microsonde nucléaire). Couplées à l'analyse sédimentologique (stratigraphie, granulométrie laser, microminéralogie, micromorphologie, etc.), les analyses et les imageries géochimiques permettent

\footnotetext{
* Laboratoire ADES - UMR 5185, CNRS-Université Bordeaux 3 - ANR Climanthrope - Maison des Suds - 12, Esplanade des Antilles - 33607 Pessac Cedex (rmaire@ades.cnrs.fr; gregory.dandurand@gmail.com; b.lans@ades.cnrs.fr).

** Centre d'Etude Nucléaire Bordeaux Gradignan (CENBG) - UMR 5084 - CNRS-Université Bordeaux 1 - ANR Climanthrope - Chemin du Solarium - 33175 Gradignan (ortega@ cenbg.in2p3.fr; deves@cenbg.in2p3.fr).

*** Laboratoire Ampère - UMR 5005 CNRS - ANR Climanthrope - Université Lyon 1 (laurent.morel@univ-lyon1).

**** Institut de Géographie - Université Paris 1 (nathalie.vanara@gmail.com).

***** INRAP et UMR 5608 CNRS TRACES/CRPPM - ANR Climanthrope - 168, Grand'Rue - 34130 Mauguio (laurent.bruxelles@inrap.fr)

******* Laboratoire EDYTEM - UMR 5204 CNRS - ANR Climanthrope - CISM, Université de Savoie - 73376 Le Bourget du Lac Cedex (Stephane.Jaillet@univ-savoie.fr ).

******* Laboratoire EPOC - UMR 5805 - Département de Géologie et Océanographie - Université Bordeaux 1 - Avenue des faculties - 33405 Talence Cedex (i.billy@epoc.u-bordeaux1.fr; p.martinez@epoc.u-bordeaux1.fr).

******** Laboratoire GEOTOP - Université du Québec à Montréal - P.B. 8888 - Succ. centre-ville - Montréal, QC, H3C 3P8 - Canada (ghaleb.bassam@uqam.ca).

********** Comité scientifique du Club Alpin Français (francois.valla@sfr.fr).
} 
d'affiner l'étude des dépôts de grotte tels que les sédiments carbonatés (spéléothèmes), les sédiments détritiques rythmés (rythmites), les glaciers souterrains ou encore les peintures rupestres préhistoriques. Formées suivant des cycles saisonniers, les stalagmites et les rythmites sont susceptibles de fournir des données importantes sur les deux principaux paramètres du climat régional, tels que l'hydrologie et la température, mais aussi sur l'impact de l'Homme en milieu urbain (spéléothèmes de tunnel). Les micro-débris et les poussières contenus dans la glace souterraine ont enregistré les conditions du paléoenvironnement par piégeage de la neige. Les peintures préhistoriques peuvent aussi être étudiées directement avec un analyseur portable XRF, sans prélèvement sur le site. A travers chaque exemple, la notion d' "effet de site » est discutée à partir de quatre exemples français (Pyrénées, Aquitaine, Charente, Rhône) et de trois exemples étrangers (Italie, Chili, Chine).

Mots clés : géochimie, dépôts de grotte, image géochimique, autoradiographie, micro-XRF, XRF core scanner, microsonde, sédimentologie, effet de site, impact anthropique.

\section{Version française abrégée}

Cet article présente les principes, les méthodes et les fonctions de l'analyse géochimique appliquée aux sédiments de grotte. Ceux-ci sont reconnus comme d'excellents enregistreurs des paléoclimats et des paléoenvironnements liés au contexte particulier du milieu souterrain. Deux grandes méthodes d'analyse géochimique sont présentées : l'autoradiographie et la fluorescence de rayons $X(X R F)$. L'autoradiographie (BetaImager) permet la détection d'éléments radioactifs dans un échantillon. Le principe consiste à placer un échantillon sur un écran BaFBr:Eu ${ }^{2+}$ radiosensible. Les cristaux BaFBr et les ions Europium absorbent l'énergie du rayonnement émis par l'échantillon. La radiation modifie l'état des ions de l'Europium de $\mathrm{Eu}^{2+}$ en $\mathrm{Eu}^{3+}$. Les électrons libérés sont fixés par les atomes de brome et forment une image sur l'écran. Cette technique s'est avérée fondamentale dans la localisation rapide des secteurs radioactifs d'un échantillon.

La multiplication et l'amélioration des techniques de fluorescence $X$ ont permis des progrès remarquables dans l'acquisition de données et la rapidité de leur traitement. L'analyseur XRF portatif permet de multiplier les analyses de terrain, de déterminer et de quantifier très rapidement les principaux éléments chimiques. En vue d'affiner l'analyse, plusieurs technologies sont utilisées en laboratoire : le core scanner Avaatech, la sonde micro-XRF Horiba XGT-7000 et la microsonde nucléaire (accélérateur Van de Graaff). Le fonctionnement du core scanner et de la sonde micro-XRF consiste à bombarder la surface de l'échantillon par un faisceau de rayons (photons), produit par une source de Rhodium. Basée sur le principe d'excitation-désexcitation des électrons, la détection des éléments chimiques se fait à partir d'un détecteur semi-conducteur de Silicium. Cette méthode n'exige pas une préparation complexe de l'échantillon. Les sédiments karstiques, disposés à plats dans des U-channels, sont analysés à sec, contrairement aux sédiments marins ou lacustres. En revanche, des fentes de dessiccation peuvent apparaître et perturber le signal. Des échantillons de plus de 1,5 m peuvent être placés dans le core scanner tandis qu'ils ne doivent pas dépasser $12 \mathrm{~cm}$ de long pour pouvoir entrer dans la chambre de la sonde micro-XRF. Les résultats semi-quantitatifs (en coups/s) sont fournis sous forme de tableaux, de diagrammes ou d'images cartographiques.

La microsonde nucléaire permet de produire un faisceau de protons de quelques MeV d'énergie grâce à l'accélérateur de particules Van de Graaff. Durant l'analyse, le faisceau balaie l'échantillon et mesure la fluorescence $X$ par spectrométrie Si $(\mathrm{Li})$. Cette méthode est appelée PIXE (Particle Induced X-ray Emission). Elle permet de rapporter la masse des éléments chimiques de $Z>10$ à une unité de surface, exprimée en $\mu \mathrm{g} / \mathrm{cm}^{2}$. Combinée à la technique RBS (Rutherford Backscattering Spectrometry), la microsonde nucléaire donne la concentration locale des éléments chimiques exprimée en $\mu \mathrm{g} / \mathrm{g}$.

L'apport des techniques géochimiques appliquées aux spéléothèmes, aux dépôts détritiques, aux glaciers souterrains et aux peintures rupestres est discuté à travers sept exemples français et étrangers. Dans les Pyrénées, l'analyse Beta-Imager sur une concrétion mixte calcitelaragonite, extraite de la grotte de la Pierre Saint-Martin, combinée à une analyse PIXE/RBS, a mis en évidence des taux anormalement élevés de $\mathrm{Sr}$ et de $U$ dans les niveaux aragonitiques et calcitiques. L'étude a montré que l'abondance d'uranium (origine inconnue) dans la calcite est liée au remplacement de l'aragonite par la calcite par un processus d'épigenèse. Dans l'Entre-deux-Mers (Gironde), une méthode similaire a été menée sur une stalagmite (TN05). L'autoradiographie a révélé une forte radioactivité dans des niveaux sombres à zircons situés à la base de la concrétion. La radioactivité est liée à la présence de thorium mis en évidence par l'analyse géochimique micro-XRF. Dans les deux exemples, les teneurs très élevées en $U(300 \mu \mathrm{g} / \mathrm{g})$ ou en Th $(280 \mu \mathrm{g} / \mathrm{g})$ perturbent l'enregistrement du signal paléo-environnemental. Les hautes teneurs en uranium ou en thorium mettent en évidence un effet de site majeur. La forte radioactivité peut s'expliquer par des infiltrations d'eau de surface qui traversent des niveaux radioactifs (paléokarsts, niveaux organiques/phosphatés, minerais) ou par des contaminations externes (cendres volcaniques, pollutions anthropiques). De plus, cette radioactivité élevée peut avoir une influence sur les résultats de datations par la méthode U/Th. L'ouverture du système géochimique pendant la diagenèse peut éventuellement modifier l'âge des spéléothèmes étudiés.

Les analyses géochimiques peuvent également s'appliquer aux sédiments détritiques de grotte. Là encore, l'effet de site est mis en évidence grâce à la caractérisation géochimique du signal paléoenvironnemental. Des études menées en Charente et en Chine ont permis de caractériser les variations hydroclimatiques à travers l'analyse micro-XRF des séries détritiques souterraines dans des contextes géomorphologiques et climatiques très différents. Le remplissage limono-argileux dans la grotte du Bois du Clos (Charen- 
te) a révélé de très fortes variations des éléments $\mathrm{Si}, \mathrm{Fe}, \mathrm{Al}$, $K$ et Ca qui ont été corrélées à la granularité et à la minéralogie des unités stratigraphiques. En Chine, le puissant remplissage de la grotte-tunnel de Dadong a enregistré les fortes crues caractéristiques du climat de mousson lors des derniers 14000 ans. Les pics de Fe sont la signature des niveaux argileux brun-rouge liés à une érosion importante des sols. De même, les influences anthropiques ont été enregistrées dans les dépôts limoneux supérieurs de la coupe (fig. 15).

D'autres analyses géochimiques sur divers échantillons ont mis en évidence les effets des impacts humains sur les milieux souterrains. A Lyon (France), dans un contexte urbanisé et industrialisé, l'étude d'une stalagmite récente a révélé, par analyses micro-XRF, des taux élevés de soufre, de cuivre, de zinc et de titane, directement en lien avec la production de charbon, de matières plastiques, etc. En Patagonie chilienne, sur l'Ille de Madre de Dios, l'analyse par mixro-XRF portatif a permis d'analyser des peintures rupestres Kawésqars (grotte Pacifique) sans prélèvement. Les teneurs élevées en fer sont liées à l'utilisation d'ocre. L'étude des grottes côtières a permis de mieux comprendre l'évolution complexe de la côte patagonienne depuis la dernière déglaciation et de caler dans le temps le rebond glacio-isostatique $(+3 \mathrm{~m})$ et l'utilisation de la grotte Pacifique par les premiers habitants de la région, les indiens Kawésqars ( Nomades de la Mer»).

Enfin, l'étude géochimique de glaciers souterrains est rare. L'exemple du gouffre de Scarasson (Alpes italiennes du Sud), site dans lequel Michel Siffre mena ses expériences "Hors du Temps » en 1962, présente un glacier stratifié révélant des centaines de couches annuelles de glace. Sa fonte s'accélère depuis 20 ans. L'origine de cette fonte est discutée. L'étude géochimique des poussières et des micro-débris sombres contenus dans les couches successives de glace met en évidence un changement d'origine et de concentration des débris provenant de l'aspiration de la neige hivernale. Cette modification des paramètres contrôle l'effet de site. En conclusion, spéléothèmes, dépôts détritiques de grotte, glace souterraine, peintures rupestres sont autant d'objets privilégiés sur lesquels les analyses géochimiques sont réalisées. Celles-ci fournissent des données variées et nouvelles dans les domaines paléoclimatiques, géoarchéologiques et géomorphologiques.

\section{Introduction}

Geochemical analysis is usually used for marine and continental sediments (Böning et al., 2007; Kido et al., 2006; Koshikawa et al., 2003) but has not been very developed for subterranean deposits (speleothems and detritic fillings) even though karst deposits are now recognised as good indicators of past and present environments all over the world (Renault, 1990; Maire et al., 1994; Genty, 2002; Fairchild et al., 2006; White, 2007; Vanara and Douat, 2010). This paper aims to show that geochemical analysis and imaging are an original and significant approach to: (i) characterise the nature of speleothems and detrital cave deposits (natural or anthropic contaminations, diagenesis, etc.); (ii) reveal the hydro-sedimentary dynamics; (iii) characterise palaeocli- mate and palaeoenvironmental variations; and (iv) specify the geomorphological evolution. This paper is part of 'Climanthrope' ANR programme managed by Richard Maire. The objective of this programme is to characterise the relationships between the site and subterranean deposits. The endokarst contains many laminated clastic and carbonated deposits which are very pertinent from an environmental standpoint. The originality of this project is to show the diversity of endokarst proxy records, their geochemical significance and the main parameters of the 'site effect' which influence the natural records. Indeed, the same types of natural archives will not register the same information in terms of transfer and sedimentation conditions because of the regional climate, the subterranean microclimate, the nature of the rocks, cave size and morphology, the position of the water table, speleogenesis, human impact, etc. This paper presents preliminary results using two different geochemical methods (X-ray fluorescence and autoradiography) through many examples and unusual subterranean deposits (tab. 1).

\section{Geochemical methods: autoradiography and X-ray fluorescence}

The recent geochemical studies by X-ray fluorescence are powerful tools that provide useful information concerning the high-resolution reconstitution of palaeoclimatic variations, palaeoenvironmental dynamics, hydrological conditions and speleogenesis. Chemical XRF imaging, combined with macro- and micro-morphological observations, mineralogical and sedimentological studies, give a good discrimination between local and regional parameters. U/Th datings (TIMS) are used to give precise complementary information about the chemistry of $\mathrm{U}$ and $\mathrm{Th}$ in speleothems, with an important application for $\mathrm{CaCO}_{3}$ diagenesis and radiometric datings.

\section{Digital autoradiography: imaging of natural radioactivity (Beta Imager)}

Digital autoradiography is a method for analysing radioactive elements. As well as being extensively used in medicine and the biological sciences (Barthe, 2007), it has proved its value in the environmental sciences (Cole et al., 2003). The method involves placing a sample on a radiosensitive screen that can detect the radioactive particles that the sample emits. For the present study, we used a Biorad Personal Molecular Imager with a $\mathrm{BaFBr}: \mathrm{Eu}^{2+}$ radiosensitive screen. The $\mathrm{BaFBr}$ crystals and the Europium ions absorb the energy of the radiation emitted by the sample. This radiation changes the state of the Europium ions from $\mathrm{Eu}^{2+}$ to $\mathrm{Eu}^{3+}$. The ejected electrons are fixed by the bromium atoms and form an image on the screen. The analysis was carried out in three stages: (i) the radiosensitive screen was first exposed to a light source of a precise wavelength, in order to eliminate any traces of previous exposures. (ii) The polished face of the sample section was then placed on the radiosensitive screen and left for the exposure period. A lead 


\begin{tabular}{|c|c|c|c|c|c|c|c|}
\hline $\mathbf{N}^{\circ}$ & $\begin{array}{l}\text { Geographical } \\
\text { situation }\end{array}$ & Types ofsites & Climate & Proxy records & Methods & $\begin{array}{l}\text { Main analysed } \\
\text { signals }\end{array}$ & $\begin{array}{l}\text { Typology of site } \\
\text { effects }\end{array}$ \\
\hline 1 & $\begin{array}{l}\text { France, Pyrenees, } \\
\text { Pierre Saint-Martin }\end{array}$ & $\begin{array}{c}\text { Large } \\
\text { moutain cave }\end{array}$ & Alpine & $\begin{array}{l}\text { Stalactite- } \\
\text { corallite } \\
\text { (low growth) }\end{array}$ & $\begin{array}{c}\text { Autoradiography } \\
\text { Microprobe } \\
\text { imagery and } \\
\text { PIXE }\end{array}$ & $\begin{array}{l}\text { Radioactive aragonite- } \\
\text { calcite (diagenesis) }\end{array}$ & $\begin{array}{l}\text { Protected dry } \\
\text { gallery }\end{array}$ \\
\hline 2 & $\begin{array}{c}\text { France, Gironde, } \\
\text { Entre-deux-Mers, } \\
\text { Trou Noir }\end{array}$ & $\begin{array}{c}\text { Low plateau } \\
\text { sinkhole- } \\
\text { resurgence cave }\end{array}$ & Oceanic & $\begin{array}{l}\text { Holocene } \\
\text { stalagmite }\end{array}$ & $\begin{array}{c}\text { Autoradiography } \\
\mu \text {-XRF analysis }\end{array}$ & $\begin{array}{l}\text { Radioactive minerals } \\
\text { (zircon contamination) }\end{array}$ & Active gallery \\
\hline 3 & France, Lyon city & Artificial tunnel & $\begin{array}{c}\text { Temperate } \\
\text { (sub-oceanic) }\end{array}$ & $\begin{array}{c}\text { Young } \\
\text { stalagmite } \\
(1962-2007)\end{array}$ & $\begin{array}{l}\mu \text {-XRF imager } \\
\text { and analysis }\end{array}$ & $\begin{array}{l}\text { Urban contamination } \\
\qquad(\mathrm{S}, \mathrm{Cu}, \mathrm{Zn})\end{array}$ & $\begin{array}{l}\text { Urban artificial } \\
\text { trapping }\end{array}$ \\
\hline 4 & $\begin{array}{c}\text { France, Charente, } \\
\text { Bois du Clos }\end{array}$ & $\begin{array}{l}\text { Low plateau } \\
\text { cave without } \\
\text { river } \\
\text { (watertable) }\end{array}$ & $\begin{array}{l}\text { Temperate } \\
\text { (oceanic) }\end{array}$ & $\begin{array}{l}\text { Silt detrital } \\
\text { sequence } \\
\text { (rhythmites) }\end{array}$ & $\mu$-XRF profile & $\begin{array}{l}\text { Clay-silt and } \\
\text { silt-sandy layers }\end{array}$ & $\begin{array}{l}\text { Chamber of } \\
\text { sedimentary } \\
\text { trapping: water } \\
\text { tables type } \\
\text { (decantation) }\end{array}$ \\
\hline 5 & $\begin{array}{l}\text { China, Hubei, } \\
\text { Dadong }\end{array}$ & $\begin{array}{l}\text { Giant Tunnel- } \\
\text { cave }\end{array}$ & $\begin{array}{l}\text { Subtropical } \\
\text { (monsoons) }\end{array}$ & $\begin{array}{l}\text { Silt detrital } \\
\text { sequence } \\
\text { (rhythmites) }\end{array}$ & $\begin{array}{l}\text { XRF profile } \\
\text { Portable } \\
\text { analyzer } \\
\text { Core-scanner }\end{array}$ & $\begin{array}{l}\text { Clay-silt and } \\
\text { silt-sandy layers }\end{array}$ & $\begin{array}{l}\text { Chamber of } \\
\text { sedimentary } \\
\text { trapping: fluvio- } \\
\text { lacustrine type } \\
\text { (monsoon) }\end{array}$ \\
\hline 6 & $\begin{array}{l}\text { Italy, South Alps, } \\
\text { Scarasson }\end{array}$ & $\begin{array}{l}\text { Alpine shaft } \\
(« \text { glaciere })\end{array}$ & $\begin{array}{l}\text { Temperate } \\
\text { (alpine) }\end{array}$ & $\begin{array}{l}\text { Subterranean } \\
\text { Glacier } \\
\text { (ice layers) }\end{array}$ & $\begin{array}{c}\mu \text {-XRF } \\
\text { analysis }\end{array}$ & $\begin{array}{l}\text { Mineral dusts } \\
\text { and debris }\end{array}$ & $\begin{array}{l}\text { Shaft of } \\
\text { accumulation/ } \\
\text { melting of } \\
\text { snow/ice }\end{array}$ \\
\hline 7 & $\begin{array}{l}\text { Chile, Patagonia, } \\
\text { Pacific Cave }\end{array}$ & $\begin{array}{c}\text { Costal } \\
\text { prehistoric cave } \\
\text { with shells and } \\
\text { paintings }\end{array}$ & $\begin{array}{l}\text { Subpolar } \\
\text { (oceanic) }\end{array}$ & $\begin{array}{c}\text { Parietal } \\
\text { paintings } \\
\text { (ocher-charcoal) }\end{array}$ & $\begin{array}{l}\text { XRF portable } \\
\text { analyzer }\end{array}$ & Ocher and charcoal & $\begin{array}{l}\text { Marine coast } \\
\text { shelter }\end{array}$ \\
\hline
\end{tabular}

Tab. 1 - Parameters of the 'site effect' in the seven studied examples.

Tab. 1 - Synthèse des paramètres de l'effet de site à partir des sept exemples présentés.

cover was placed over the concretion and the radiosensitive screen to protect the system from cosmogenic radiation and to limit background noise. (iii) After several days, the samples were removed from the radiosensitive screen, which was scanned to recover the radiographic image. Quantitative analysis was carried out by using a calibration curve established from calcium carbonate pellets with a known amount of uranium: $0,10,50,100,250,500$ and $1000 \mu \mathrm{g} / \mathrm{g}$, exposed simultaneously with the sample.

\section{Portable XRF analyser}

The handheld Thermo Scientific Niton XRF analyser is designed for portable elemental analysis. It weighs $0.8 \mathrm{~kg}$ (Niton XLt 700) and can be carried easily. Batteries provide 6-12 h of continuous use. The chemical analysis is non-destructive and enables a rapid determination of the main chemical elements in the range from Ti to $\mathrm{Pu}$. The excitation method uses a miniaturised X-ray tube, thereby eliminating radioactive material constraints. The measurement window is $20 \mathrm{~mm}$ x $10 \mathrm{~mm}$. The sediment (powder or solid) does not require any special preparation. Semi-quantitative information can be obtained as the sensitivity of the XRF analyser is limited to elements with a concentration above $1 \%$.

\section{Avaatech XRF Core Scanner}

The Avaatech XRF Core Scanner is an X-ray fluorescence logging system developed by the Royal Netherlands Institute for Sea Research (NIOZ) for split sediment cores (fig. 1). It provides quick high-resolution (down to $0.1 \mathrm{~mm}$ ) records of the chemical composition of rocks and sediment (from $\mathrm{Al}$ to $\mathrm{U}$ ). The tube voltage of the Rhodium source can be adjusted from $5 \mathrm{KV}$ to $50 \mathrm{KV}$ to provide optimum settings for selected elements. The detector is a $15 \mathrm{~mm}^{2} \mathrm{Si}$-crystal PIN diode. This non-destructive method does not need any complex preparation of the sample but, because of the heterogeneity of the surface (water content, irregularity and grain size changes), the results are semi-quantitative (in counts/s). To obtain a quantitative concentration, the data must be completed by classical geochemical analysis. For the humid marine and lacustrine cores, the sediment has to be covered with a thin Ultralene film. For karst sediments, it is possible to analyse easily dry sediment without film, but they present desiccation cracks. The size of the analysed area can be adjusted in both directions, down core from $10 \mathrm{~mm}$ to $0.1 \mathrm{~mm}$ (resolution), cross core from $2 \mathrm{~mm}$ to $16 \mathrm{~mm}$. The maximum detection depth decreases with the atomic weight: $4 \mathrm{~mm}$ for Ba, 1-2 mm for $\mathrm{Sr}, 1 \mathrm{~mm}$ for $\mathrm{Fe}, 0.5 \mathrm{~mm}$ for $\mathrm{Ca}$ and 
$0.05 \mathrm{~mm}$ for $\mathrm{Al}$ (Richter et al., 2006). This technique includes a preliminary stratigraphic interpretation.

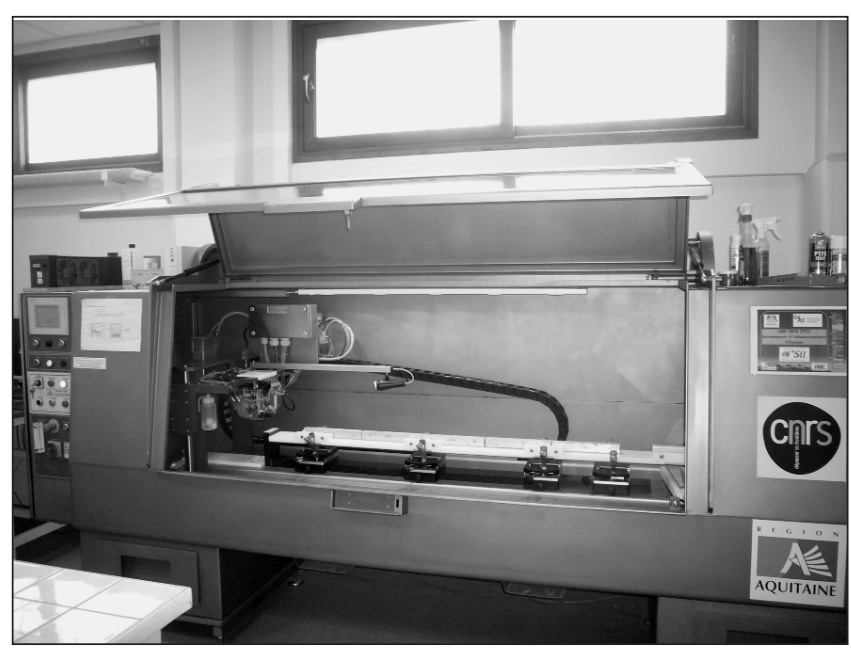

Fig. 1 - The Avaatech XRF Core Scanner (EPOC laboratory, university Bordeaux 1).

Fig. 1 - Photo de I'XRF Core Scanner Avaatech (laboratoire EPOC, université Bordeaux 1).

\section{Micro-XRF analysis}

The principle of micro-XRF analysis is based on the detection of the fluorescence $\mathrm{X}$ issued locally during the scanning of the sample surface by the X-ray beam obtained by bombardment of the rhodium anode with a beam of electrons (fig. 2). Therefore, the radiation source is the sum of two contributions: (i) continuous background radiation, corresponding to the bremsstrahlung (deceleration radiation) of electrons in the rhodium plate, (ii) a spectrum of discrete lines corresponding to the radiative decay mode of the rhodium atoms of the anode. The X-ray beam is focused onto the sample surface through a waveguide with an output diametre of $10 \mu \mathrm{m}$ or $100 \mu \mathrm{m}$, which is ultimately the size of the beam on the sample. The fluorescence $\mathrm{X}$ is measured by a semiconductor detector (high purity silicon). The X-ray source and the detector are separated from the analysis chamber by a thin polymer window, allowing in-air analysis to be performed with minimum sample preparation. The distance between the sample surface and the exit window is kept below $1 \mathrm{~mm}$ in order to minimise the absorption of low-Z element fluorescence by the remaining air layer. Depending on the matrix composition, the limits of detection (lod) for light elements $(\mathrm{Z}<15)$ are in the range $300 \mu \mathrm{g} / \mathrm{g}$ to $1000 \mu \mathrm{g} / \mathrm{g}$, while for heavier elements $(Z \geq 15)$ they are in the $50 \mu \mathrm{g} / \mathrm{g}$ to $100 \mu \mathrm{g} / \mathrm{g}$ range, except for $\mathrm{K}(1000 \mu \mathrm{g} / \mathrm{g})$ due to interference between Rh L-lines and K K-lines. Quantification of element concentration is performed using a fundamental parameter method provided by the manufacturer after instrument calibration (geometrical setup, excitation source and detection system). Accuracy has been determined from the analysis of standard soil reference materials (NIST DNC-2, NIST BIR1 , NIST BCR-2) and varies from $1 \%$ to $20 \%$, depending on element concentration, for all elements with a concentration higher than $1000 \mu \mathrm{g} / \mathrm{g}$. The spectrum of X-rays emitted by the irradiated sample can be used to determine the sample's chemical composition, as every chemical element has its own X-ray signature. The analysis time is an important factor as the signal-to-noise ratio is proportional to $\sqrt{ } \mathrm{N}(\mathrm{N}=$ peak area). Micro-XRF analysis offers several advantages: a non-destructive and high-resolution analysis, a qualitative and quantitative method applicable to different grain size sediments and rocks, profiles and mapping images, and simple preparation of samples.

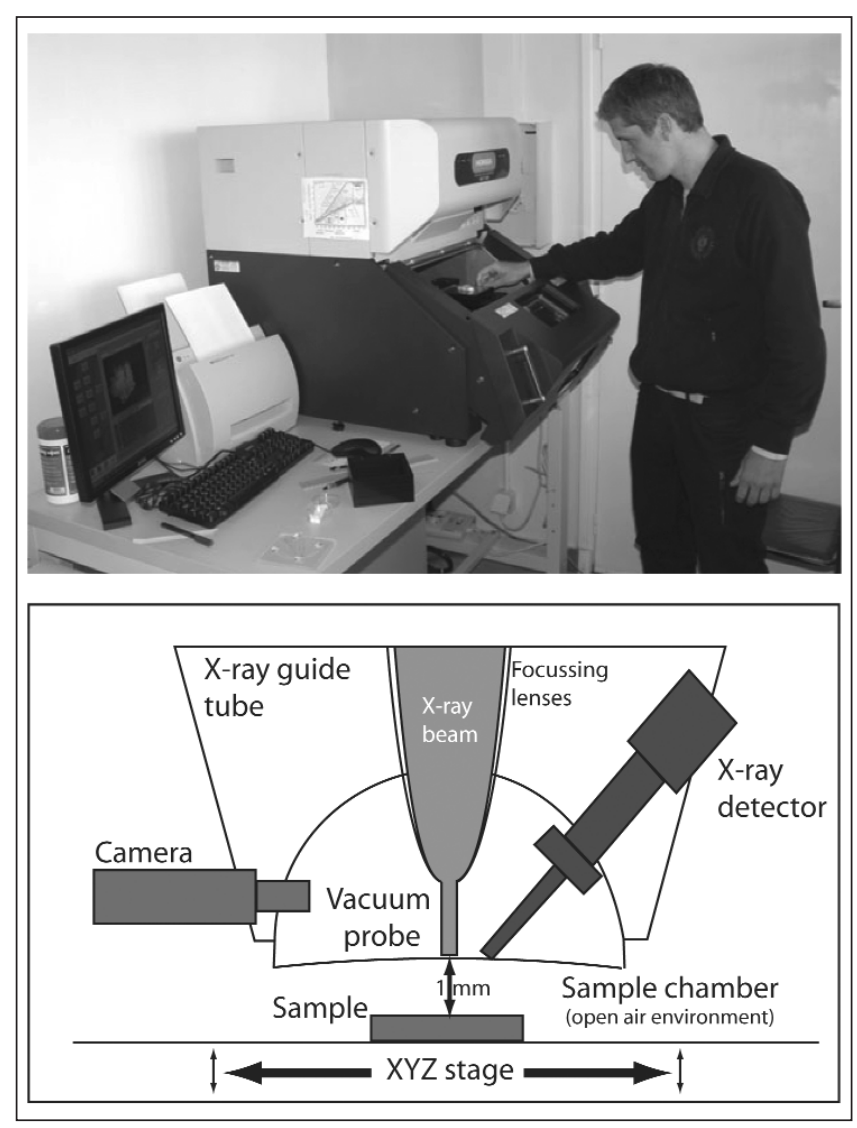

Fig. 2 - The micro-XRF Horiba at CENBG, XGT-7000 model (Centre d'Etudes Nucléaires de Bordeaux Gradignan, university Bordeaux 1).

Fig. 2 - Photo du micro-XRF de chez Horiba, modèle XGT-7000 (Centre d'Etudes Nucléaires de Bordeaux Gradignan, université Bordeaux 1).

\section{Nuclear microprobe analysis}

The nuclear microprobe enables microscopic chemical mapping of trace elements on numerous types of environmental and geological samples. The methodological aspects of the nuclear microprobe analysis of speleothems, and quantitative analysis validation, have been described in a technical note (Ortega et al., 2003). The most common procedure is to produce an incident proton beam of a few $\mathrm{MeV}$ by a particle accelerator to measure the X-ray fluorescence 
with a $\mathrm{Si}(\mathrm{Li})$-detector. This method is called Particle Induced $\mathrm{X}$-ray Emission (PIXE) and is generally combined with Rutherford Backscattering Spectrometry (RBS). The PIXE technique, sensitivity $10^{-15} \mathrm{~g}$, can measure the mass of chemical elements of $Z>10$, per unit area (in $\mu \mathrm{g} / \mathrm{cm}^{2}$ ). The $\mathrm{X}$-ray peak area of an element $\mathrm{Z}$ is directly proportional to its content in the sample. For thin section observations, the RBS method can determine the mass per unit area (in $\mathrm{g} / \mathrm{cm}^{2}$ ) of the matrix elements $(Z>1)$. The simultaneous implementation of these two techniques can thus normalise the amount of trace elements obtained by PIXE and the mass matrix obtained by RBS, to give the local concentration of chemical elements expressed in $\mu \mathrm{g} / \mathrm{g}$.

Nuclear microprobe analysis has not yet been used a great deal. It was performed on a Pyrenean speleothem (Maire et al., 2009 a to d; Ortega et al., 2005 and 2010) using the nuclear microprobe beamline at the AIFIRA facility (Applications Interdisciplinaires des Faisceaux d'Ions en Région Aquitaine). Chemical maps of the elements were obtained using the Ka X-ray emission lines for Ca (3.69 keV), Zn (8.64 $\mathrm{keV}$ ), and $\mathrm{Sr}$ (14.16 keV), and Lb1 for U (17.22 keV). Using 3.0 MeV protons, the maximum scan size achievable with the AIFIRA nuclear microprobe is $683 \mu \mathrm{m} \times 683 \mu \mathrm{m}$. In the colour distribution maps, the element concentration increases from black to yellow. In the black and white distribution maps, each chemical map is coded with 256 levels of grey, the element concentration increasing from black (minimum) to white (maximum). The X-ray fluorescence maps were normalized by local sample mass using RBS data on $\mathrm{CaCO}_{3}$ content to obtain quantitative results expressed in terms of $\mu \mathrm{g}$ of element per $\mathrm{g}$ of sample. The local sample mass was calculated from aerial mass RBS data using calcite and aragonite densities, $2.71 \mathrm{~g} / \mathrm{cm}^{3}$ and $2.94 \mathrm{~g} / \mathrm{cm}^{3}$ respectively.

\section{Results for speleothems, detrital rhythmites, ice, and prehistoric paintings}

\section{Speleothems (France)}

\section{Pierre Saint-Martin Cave (Pyrenees, France) - Beta Imager and Microprobe}

The Pierre Saint-Martin Cave (fig. 3 and fig. 4) is one of the world's largest, with a mapped length of $80 \mathrm{~km}$ and a depth of $1342 \mathrm{~m}$ (Maire et al., $2009 \mathrm{a}$ and b). It is situated in Cretaceous limestone at the contact with underlying Palaeozoic strata of the Pyrenean axial zone. The study site is located in the Aranzadi Gallery, $300 \mathrm{~m}$ long and $30 \mathrm{~m}$ wide, which is the former course of the main underground river prior to the collapse of the chamber floor (Verna Room) and piracy by the river into the underlying Devonian limestones. This collapse has been dated at around $200 \mathrm{ka}$ (Maire, 1990). A specific research project focused on the relationship between the remobilisation of uranium and strontium during recrystallisation (Ortega et al., 2005). A white corallite stalactite was sam-

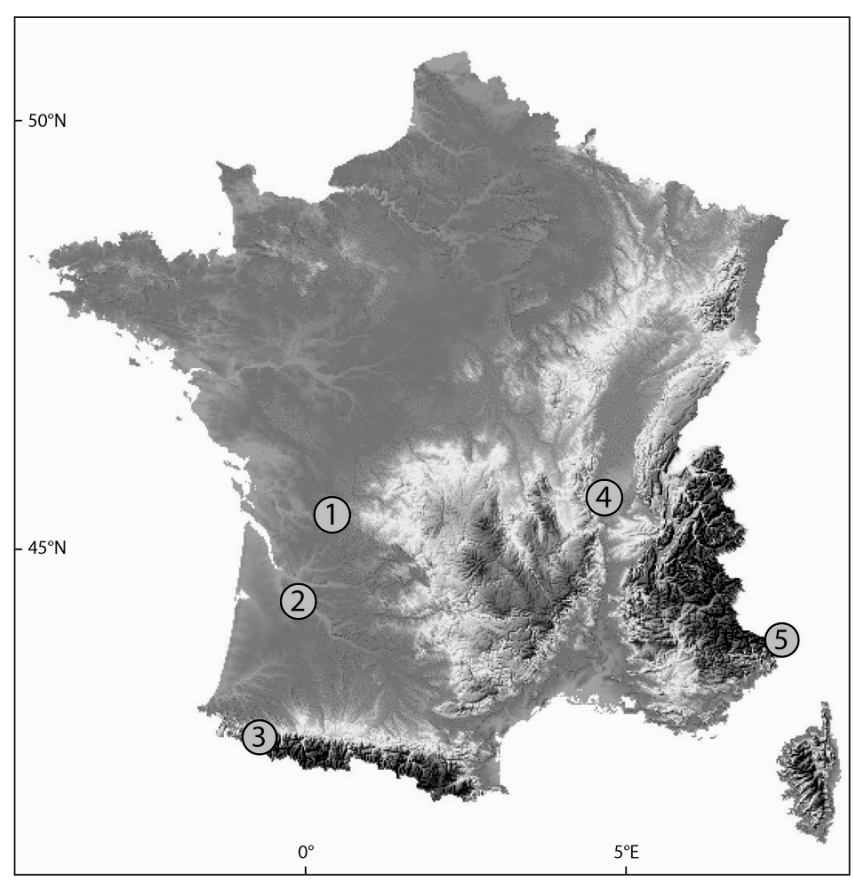

Fig. 3 - Location map of French and Italian study sites. 1: karst of La Rochefoucauld (Charente); 2: low plateau of Entre-deux-Mers (Gironde); 3: Pierre Saint-Martin Cave (Pyrenees); 4: Lyon; 5: Scarasson Cave (Marguareis, Italy).

Fig. 3 - Localisation des secteurs d'étude français et italiens. 1 : Le karst de La Rochefoucauld (Charente) ; 2 : Le bas plateau de l'Entre-deux-Mers (Gironde) ; 3 : La Pierre Saint-Martin (Pyrénées) ; 4. Lyon ; 5 : La grotte de Scarasson (Marguareis, Italie).

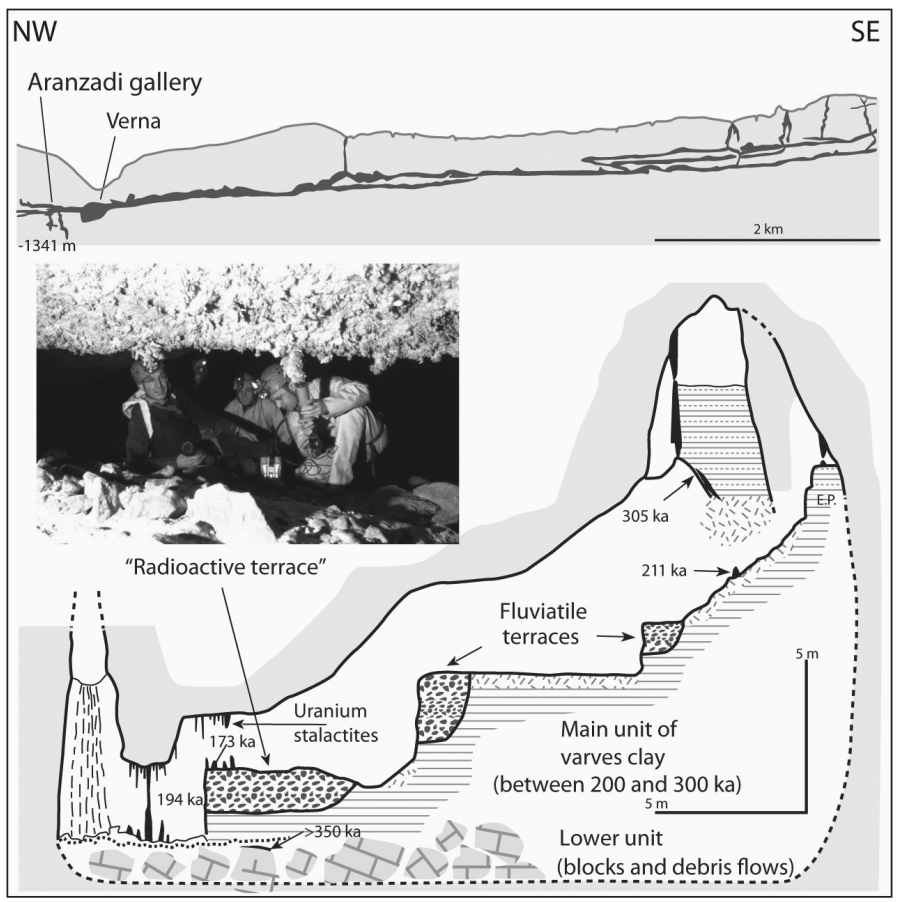

Fig. 4 - Pierre Saint-Martin Cave (Pyrenees, France). Synthetic section of the Aranzadi gallery and its deposits of Middle Pleistocene near the 'Radioactive Terrace'. Gamma scintillometer measurements give 100-400 counts/s.

Fig. 4 - Grotte de la Pierre Saint-Martin (Pyrénées, France). Coupe synthétique de la galerie Aranzadi et de ses dépôts du Pléistocène Moyen. Les mesures au scintillomètre gamma donne 100-400 coups/s. 
Fig. 5 - Sample of corallite speleothem in the Aranzadi gallery (Pierre Saint-Martin Cave, Pyrenees, France). A: Autoradiography of the vertical polished section showing the radioactive aragonite. B: Vertical polished section in reflected light, showing aragonite (white) and calcite (grey) with location and results of the U-series dating (in $\mathrm{ka} \pm 2 \sigma$; GEOTOP laboratory, Montreal).

Fig. 5 - Spéléothème coralloïde prélevé dans la galerie Aranzadi (Grotte de la Pierre Saint-Martin, Pyrénées, France). A : Autoradiographie d'une section polie mettant en évidence les niveaux d'aragonite radioactifs.

$B$ : Section polie en lumière réfléchie, indiquant les couches d'aragonite en blanc et les couches de calcite en gris, la localisation et les résultats des datations U/Th (en ka $\pm 2 \sigma$; laboratoire GEOTOP, Montréal).

pled from the ceiling above the so-called 'Radioactive Terrace'. This speleothem was characterised by a combination of two mineral phases, aragonite and calcite, and showed evidence of partial recrystallisation that occurred during its growth. A first radioactive mapping was performed with the Beta Imager which revealed a high radioactivity in the white aragonite (fig. 5). The PIXE and RBS analysis (fig. 6) showed that the samples contained significant amounts of uranium (from 89 $\pm 11 \mu \mathrm{g} / \mathrm{g}$ to $350 \pm 30 \mu \mathrm{g} / \mathrm{g}$ in the aragonite and from 11 $\pm 6 \mu \mathrm{g} / \mathrm{g}$ to $19 \pm 4 \mu \mathrm{g} / \mathrm{g}$ in the calcite) and strontium (from $4910 \pm 20 \mu \mathrm{g} / \mathrm{g}$ to $18600 \pm 100 \mu \mathrm{g} / \mathrm{g}$ in the aragonite layers and from $440 \pm 10 \mu \mathrm{g} / \mathrm{g}$ to $1100 \pm 20 \mu \mathrm{g} / \mathrm{g}$ in the calcite layers). Calcite and aragonite are polymorphs of calcium carbonate. They differ in their crystal structure in that calcite is hexa-coordinated whereas aragonite is nona-coordinated. The larger coordination site of the aragonite can trap cations of steric radius greater than that of $\mathrm{Ca}^{2+}$, such as $\mathrm{Sr}^{2+}$ and $\mathrm{UO}_{2}{ }^{2+}$. However, the origin of $\mathrm{U}$ and $\mathrm{Sr}$ in these speleothems is still unknown. They were probably brought by the percolation water that washed through some U-rich layers, like organic matter levels or phosphatic layers, ores, and palaeokarsts. The $\mathrm{Sr}$ and $\mathrm{U}$ contents found in the calcitic parts of the speleothems are abnormally high. This abundance of uranium in the calcite, as with the abnormal strontium content, is a strong argument in favour of diagenesis with replacement of aragonite by calcite. The primary aragonite structure can trap the tricarbonated-uranyl anion $\left[\mathrm{UO}_{2}\left(\mathrm{CO}_{3}\right)_{3}{ }^{4-}\right]$. During the recrystallisation of primary aragonite to neo-formation calcite, uranium is expelled. This phenomenon is already known in ancient marine calcium carbonate deposits. In coral reefs, the recrystallisation of aragonite to calcite and dolomite is accompanied by a loss of $U$ and can lead to erroneous dating (Lalou, 1985). Several analyses by the U/Th dating TIMS method (GEOTOP $\mathrm{lab}$ ), in aragonite and neo-formation calcite, situated on the same stratigraphic level, showed a slight difference: 31977 \pm 477 a and $29737 \pm 372$ a respectively (fig. 5). The chemical analyses confirmed the PIXE results for U content: $166.540 \pm 1.074 \mu \mathrm{g} / \mathrm{g}$ in original aragonite and $12.675 \pm$

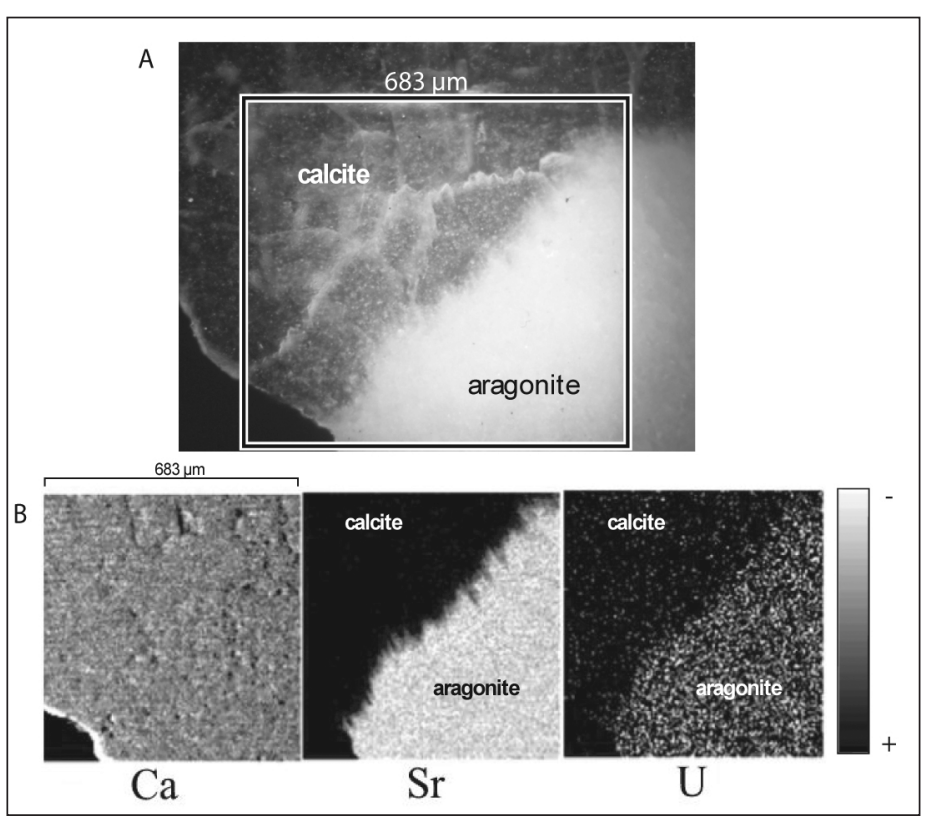

Fig. 6 - Thin section in epifluorescence (UV light) showing dark layers that are non-fluorescent in the irradiated zone but fluorescent in the non-irradiated part (A). Ca, Sr, U mapping; Sr and $U$ are concentrated in aragonite (B). Element concentration increases from white to black.

Fig. 6 - Epifluorescence (lumière UV) sur lame mince (A). Les couches foncées sont non-fluorescentes dans la zone irradiée, mais fluorescentes dans la partie non-irradiée. Cartographie des éléments $\mathrm{Ca}$, Sr et U; Sr et U sont concentrés dans l'aragonite (B). Les teneurs les plus faibles apparaissent en blanc, les plus fortes en noir.

$0.372 \mu \mathrm{g} / \mathrm{g}$ in neo-calcite. Two other analyses $2 \mathrm{~cm}$ below gave $206.787 \pm 1.060 \mu \mathrm{g} / \mathrm{g}$ in aragonite and $15.672 \pm 0.057$ $\mu \mathrm{g} / \mathrm{g}$ in calcite. The ${ }^{232} \mathrm{Th}$ content is very low $(0.6 \mathrm{ppb}$ to $1.5 \mathrm{ppb})$ and the ratio ${ }^{230} \mathrm{Th} / 232 \mathrm{Th}$ is exceptionally high: 13378 and 36422 in calcite and 195693 in aragonite. A last experiment using XANES spectroscopy at the ESRF (European Synchrotron Radiation Facility, Grenoble) indicated that $\mathrm{U}$ is present in its hexavalent state in both aragonite and calcite. For speleothems, U(IV) is present only in reducing conditions (Ortega et al., 2005).

The karst of Entre-deux-Mers (Gironde, SW France) - Beta Imager and micro-XRF

In the low plateau of Entre-deux-Mers near Bordeaux (Gironde), most of the caves are active systems (sinkholeresurgence) located in the Oligocene porous limestone 


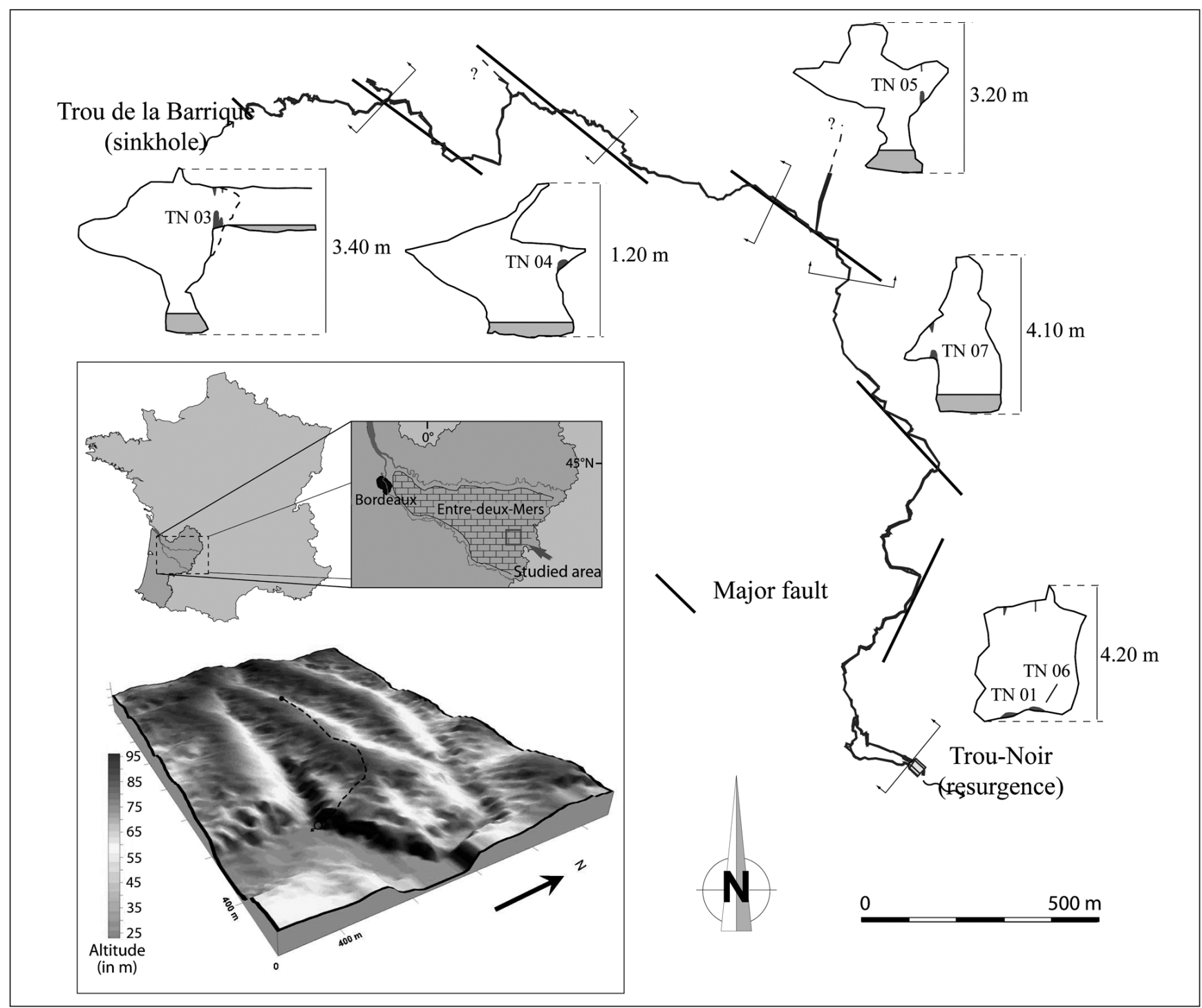

Fig. 7 - Map of the Trou Noir Cave (Entre-deux-Mers, Gironde, France).

Fig. 7 - Plan et localisation du réseau du Trou Noir (Entre-deux-Mers, Gironde, France).

(fig. 3 and fig. 7). The speleothems of the Trou Noir Cave reveal a significant variability in hydroclimatic conditions with mud layers interbedded into calcite because of floods and also the presence of detrital particles in the laminated calcite (Lans et al., 2006). One stalagmite (TN05) was chosen for geochemical analysis. First of all, autoradiography by Beta-Imager revealed high radioactive levels in the sample (fig. 8). The uranium content reached about $280 \mathrm{ppm}$ in several areas of the lower part. This result is exceptional compared to other sites of the region. The values are some of the highest known for speleothems (Ortega et al., 2005). In the karst of Entre-deux-Mers, the Stampian limestone concentrates natural radioactivity contents. Thus, micromorphological observations of thin sections show a porous structure in which numerous wide black detrital particles are located (fig. 8). They can be recovered by dissolving them in acid. The mineral determination indicates that they are composed of $80 \%$ quartz and $>10 \%$ zircons (fig. 8) along with other heavy minerals such as brown quartz, staurotide and rutile. Finally, these particle samples were analysed by micro-XRF (fig. 8). The results show an abundant presence of $\mathrm{Ti}, \mathrm{Fe}$ and $\mathrm{Zr}$. However, a focus between the $\mathrm{Fe}$ and $\mathrm{Zr}$ rays indicates the presence of $\mathrm{Hf}, \mathrm{Zn}(180 \mathrm{ppm})$ and Th. The high radioactivity recorded here is certainly due to thorium. In mineralogy and geochemistry, zircons with actinides are known to be the main radioactive minerals in granitoids and syenites with a substitution of zirconium by uranium and/or thorium (up to $1.5 \% \mathrm{U}_{3} \mathrm{O}_{8}$ and $2.1 \% \mathrm{ThO}_{2}$; Bariand et al., 1984). In this example, the radioactivity of zircon of Pyrenean origin (Alvinerie, 1969) is due to thorium as the XRF spectrum attests.

\section{Micro-XRF of a stalagmite formed in an urban environment: example of an underground tunnel of Lyon}

Speleothems are now well known as good palaeoclimate archives but their potential for monitoring anthropogenic pollution is largely unexplored. Geochemical analysis of 


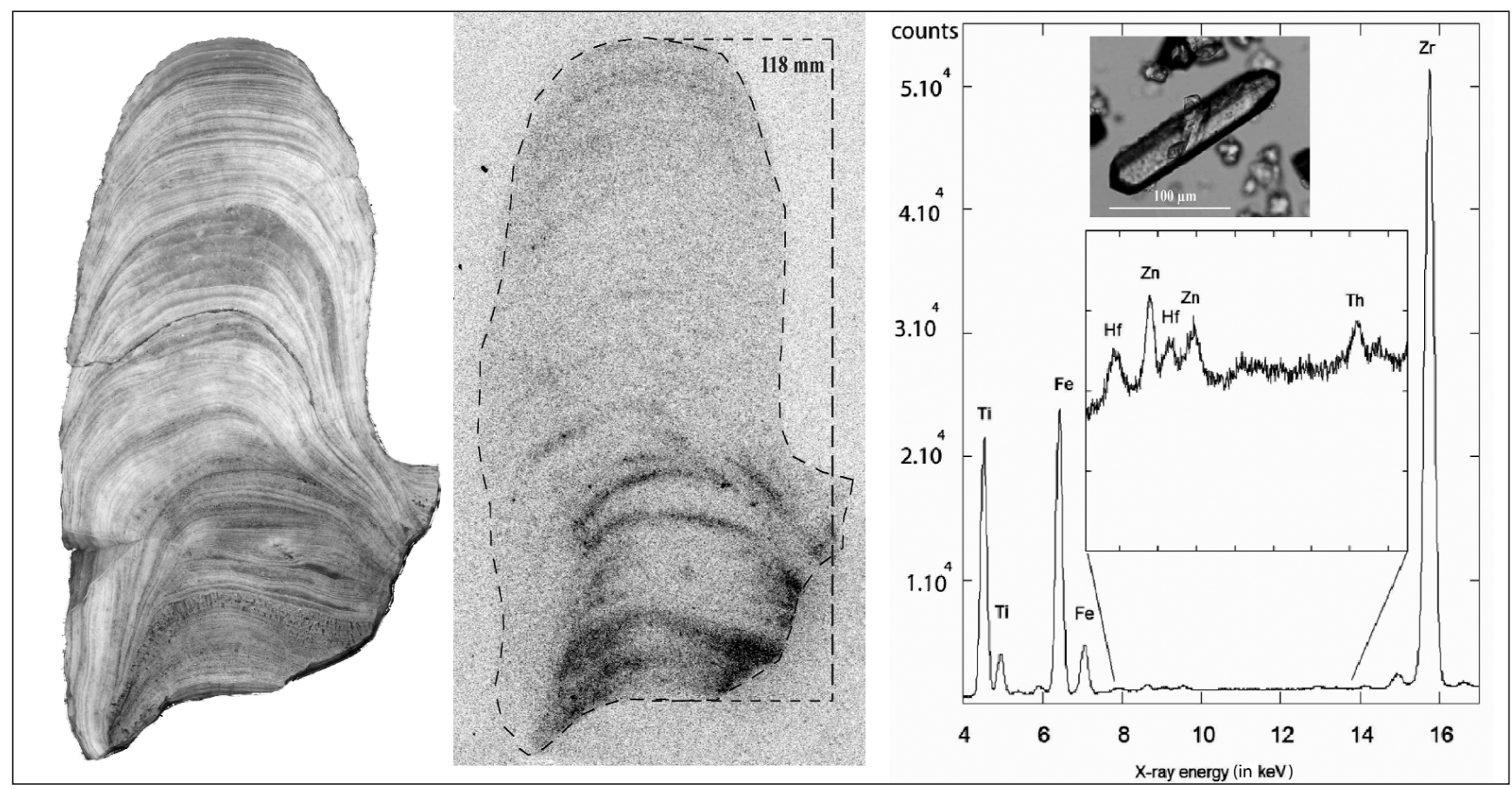

Fig. 8 - Polished section of TN05 (A). The darkest layers contain detrital grains. Radioactivity imaging in TN05 on Beta-Imager related to the most detritic levels (B). Micro-XRF spectrum of a zircon grain (C). The radioactivity is due to thorium.

Fig. 8 - Section polie de la stalagmite TN05 (A). Les couches les pus sombres contiennent des grains détritiques. Autoradiographie au Beta-Imager (B). Spectre micro-XRF d'un zircon (C). Le thorium est à l'origine de la radioactivité dans la concrétion.

\begin{tabular}{|c|c|c|c|c|}
\hline Elements & Mass (in \%) & 3 sigma & $\begin{array}{c}\text { Atomic } \\
\text { (in \%) }\end{array}$ & $\begin{array}{c}\text { Intensity } \\
\text { (in cps/mA) }\end{array}$ \\
\hline $\mathrm{S}$ & 0.51 & 0.02 & 0.61 & 217.31 \\
\hline $\mathrm{Ca}$ & 99.24 & 0.01 & 98.82 & 25924.44 \\
\hline $\mathrm{Fe}$ & 0.03 & 0.01 & 0.02 & 8.71 \\
\hline $\mathrm{Cu}$ & 0.02 & 0.01 & 0.01 & 9.82 \\
\hline $\mathrm{Zn}$ & 0.07 & 0.01 & 0.04 & 40.05 \\
\hline $\mathrm{Sr}$ & 0.14 & 0.03 & 0.03 & 175.25 \\
\hline
\end{tabular}

Tab. 2 - Geochemical results for the contaminated stalagmite of Lyon (France).

Tab. 2 - Résultats des analyses XRF de la stalagmite contaminée de Lyon (France).

several concretions collected in an underground tunnel of the city of Lyon in 2007 has allowed the identification and characterisation of seasonal and anthropogenic signals. The tunnel was built in the 19th century to collect water but it is no longer functional. A sample of a small stalagmite extracted from a tunnel located near the National Conservatory of Music and Dance shows abnormally high levels of sulphur, iron, copper, zinc and titanium (tab. 2). Approximately 39 annual laminae were counted. The base of the concretion is dated 1968. It is thus young and pure and does not represent levels of erosion or recrystallisation. The results of geochemical mapping raise two types of interpretation (fig. 9). The first is related to the distribution of chemical elements in the stalagmite. Only $\mathrm{S}$ has a distribution consistent with laminae of the concretion. $\mathrm{Ca}, \mathrm{Sr}$ and $\mathrm{P}$ are homogeneously distributed.

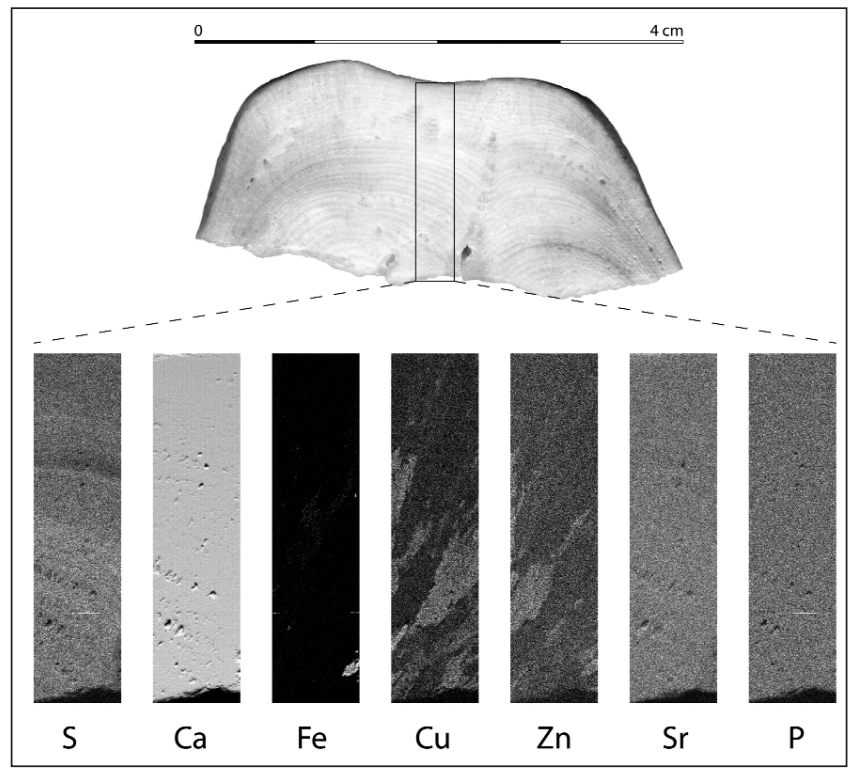

Fig. 9 - Geochemical mapping of the stalagmite C1-Lyon (Lyon city tunnel, France). The elements do not reproduce the spatial distribution of laminae. Their distribution is concentrated in the form of oblique marks that are associated with the crystalline fabric.

Fig. 9 - Images géochimiques de la concrétion C1-Lyon (contexte urbain lyonnais, France). La distribution des éléments, exceptée celle du soufre, ne se superpose pas aux lamines de croissance. Elle prend la forme de tâche oblique en lien avec la fabrique cristalline.

The images of the spatial distribution of $\mathrm{Fe}, \mathrm{Cu}$ and $\mathrm{Zn}$ show an original emission. These elements do not reproduce the spatial distribution of laminae, rather they are concentrated 
in the form of oblique marks that are associated with the crystalline fabric. Other concretions that were analysed show the same type of phenomenon. This is an artefact related to a scattering problem based on the general orientation of calcite crystals. Only certain chemicals are affected, depending on their peak energy. The emission of radiation of each chemical element depends on a certain amount of energy that results in a peak. However, the peak energy of $\mathrm{Fe}, \mathrm{Cu}$ and $\mathrm{Zn}$ appears to be clearly influenced by the orientation of calcite crystals. This is not the case for $\mathrm{S}, \mathrm{Ca}, \mathrm{Sr}$ and $\mathrm{P}$. This new observation in the chemical imaging of speleothems involves complex crystallochemical phenomena. The second interpretation concerns the high levels of sulphur. These are generally associated with anthropogenic or volcanic emissions (Frisia et $a l ., 2005)$. However, the high S content $(>5000 \mu \mathrm{g} / \mathrm{g})$ and the very recent age of the stalagmite show that $\mathrm{S}$ is the typical signature of industrial pollution. Because of the significant use of coal in the Lyon region until the mid-1970s, sulphur recorded in this speleothem would come from the emission of sulphur dioxide $\left(\mathrm{SO}_{2}\right)$ by coal burning. The low concentration of sulphur in the upper part of the concretion is an argument in favour of this hypothesis.

\section{Detrital rhythmites (France, China) \\ The karst of La Rochefoucauld (Charente, SW France) - Micro-XRF}

The karst of La Rochefoucauld (Charente, SW France; fig. 3 and fig. 10) is one of the largest French karst areas $\left(550 \mathrm{~km}^{2}\right)$.

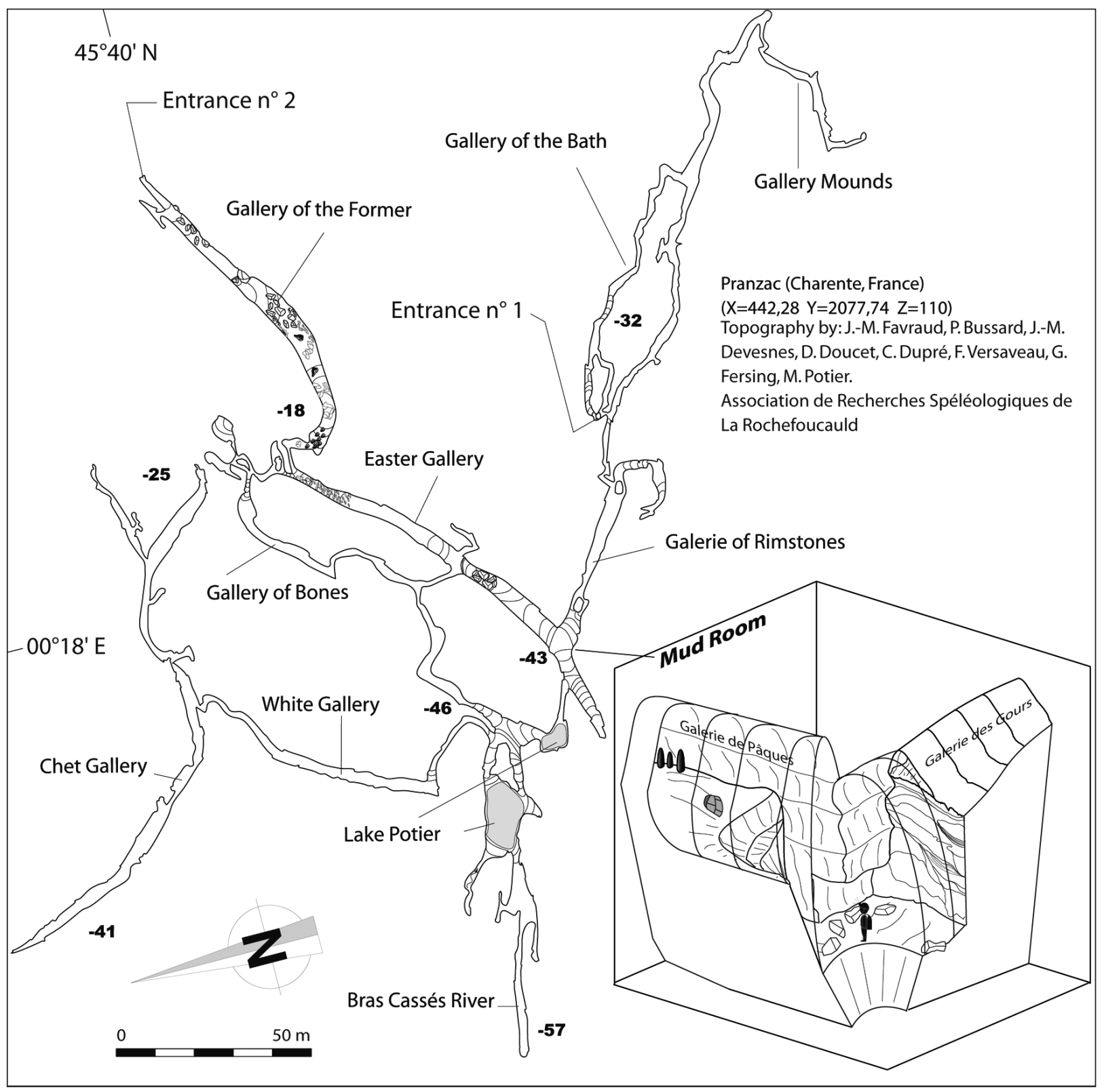

Fig. 10 - Map of the Bois du Clos Cave and 3D view of the Mud Room (Charente, France).

Fig. 10 - Plan de la grotte du Bois du Clos et bloc-diagramme de la salle de la Boue (Charente, France). 
The Touvre springs are the only outlet and the second biggest French resurgence $\left(13 \mathrm{~m}^{3} / \mathrm{s}\right)$ after the Fontaine of Vaucluse (SE France). Using the micro-XRF analyser, continuous sequential profiles of six elements, $\mathrm{Al}, \mathrm{Si}, \mathrm{K}, \mathrm{Ca}, \mathrm{Ti}$ and $\mathrm{Fe}$, were obtained in a remarkable sedimentary section more than $5 \mathrm{~m}$ high (Mud Room) from the Bois du Clos Cave, located $5 \mathrm{~km}$ north-east of the Touvre springs. X-ray fluorescence analysis (XRF) was performed on $17 \mathrm{U}$-channel samples 20 $\mathrm{cm}$ above the core in order to determine the percentage composition of the major elements. $\mathrm{Al}, \mathrm{Si}, \mathrm{K}, \mathrm{Ca}, \mathrm{Ti}$ and $\mathrm{Fe}$ are usually used for reconstructing palaeoclimate and palaeoenvironmental changes. Several geochemical studies applied to marine, lacustrine or cave deposits have already shown the interest of these elements. For instance, the study of variations in $\mathrm{Ca}, \mathrm{Fe}$ and $\mathrm{Ti}$ contents in a marine sediment core from the Cariaco Basin (Peterson et al., 2000) identified depositions linked with terrigenous input and those related to a higher biological productivity, both interpreted as a response to an increase in regional precipitations during interstadial times. $\mathrm{N}$. Katsuta et al. (2007) made sequential profiles of seven elements ( $\mathrm{Al}, \mathrm{Si}, \mathrm{K}, \mathrm{Ca}, \mathrm{Ti}, \mathrm{Mn}$ and $\mathrm{Fe}$ ) in the lacustrine sediment from Lake Suigetsu, Japan, in order to characterise climatic and tectonic random events like volcanic eruptions, earthquakes or heavy rains. S. Cuven (2009) showed the strong relationship between the $\mathrm{Zr} / \mathrm{K}$ ratio from clastic-clay varves in Cape Bounty East Lake (Canadian High Arctic) and greenhouse gas concentration in the atmosphere, low volcanism and high solar irradiance activities. Geochemical studies have already been carried out on cave deposits. Using this technique, correlated with the morphological analysis of single quartz grains and grain size analysis, N. Darrénougué et al. (2009) characterised the origin of an aeolian material deposited in Blanche Cave, South Australia. The aim of this study is to determine the chemical response to regional climatic changes and local conditions (Dandurand et al., 2010). The grain-size analysis showed that the lower levels of the very fine detrital silt-clayey sequence are related to groundwater fluctuations (Touvre Basin) in a low altitude plateau. The upper levels are marked by rhythmic and deep sandy channels that indicate alternating phases of groundwater settling and palaeoflow paths related to local sinkholes. Thereafter, the deposit was washed out (withdrawal), then sealed by stalagmites, currently functional and allocated by ${ }^{14} \mathrm{C}$ to the MIS 3. Micro-XRF analysis was performed using the Horiba X-ray analytical microscope XGT-7000 at the Centre d'Etudes Nucléaires de Bordeaux Gradignan (CENBG). Sediment samples, $2 \mathrm{~cm}$ thick, were cut into $10-\mathrm{cm}$ long slabs. The sample surface was polished flat. To avoid problems of condensation on the lens between the detector and the sample surface, it was decided to do the analysis without plastic film and to dry samples in an oven at $80^{\circ} \mathrm{C}$ for $24 \mathrm{~h}$. The disadvantage of this technique is the shrinking of the sediment, estimated at approximately 5\%. This volume reduction creates some desiccation cracks that can interfere with the detection and quantification of chemical elements, particularly for the lighter ones. In addition, the total height of the sedimentary section is reduced by about $5 \%$. Every sedimentary unit is characterised by grain-size variations and a variability of the elements $\mathrm{Ca}, \mathrm{Fe}, \mathrm{Ti}, \mathrm{K}, \mathrm{Si}$ and $\mathrm{Al}$ (fig. 11). The geochemical profile provides a good correlation with grain facieses. In this way, it can characterize palaeohydrological variability recorded in a particular chamber as a decantation place for fluvial and karst water table sedimentation. In brief, $\mathrm{Si}(\sim 48 \%), \mathrm{Fe}(\sim 23.5 \%)$ and $\mathrm{Al}(\sim 13.5 \%)$ are the three dominant elements, while $\mathrm{K}(\sim 4.2 \%), \mathrm{Ca}(\sim 3 \%)$ and $\mathrm{Ti}$ $(\sim 2.5 \%)$ are secondary. From the bottom to the top of the

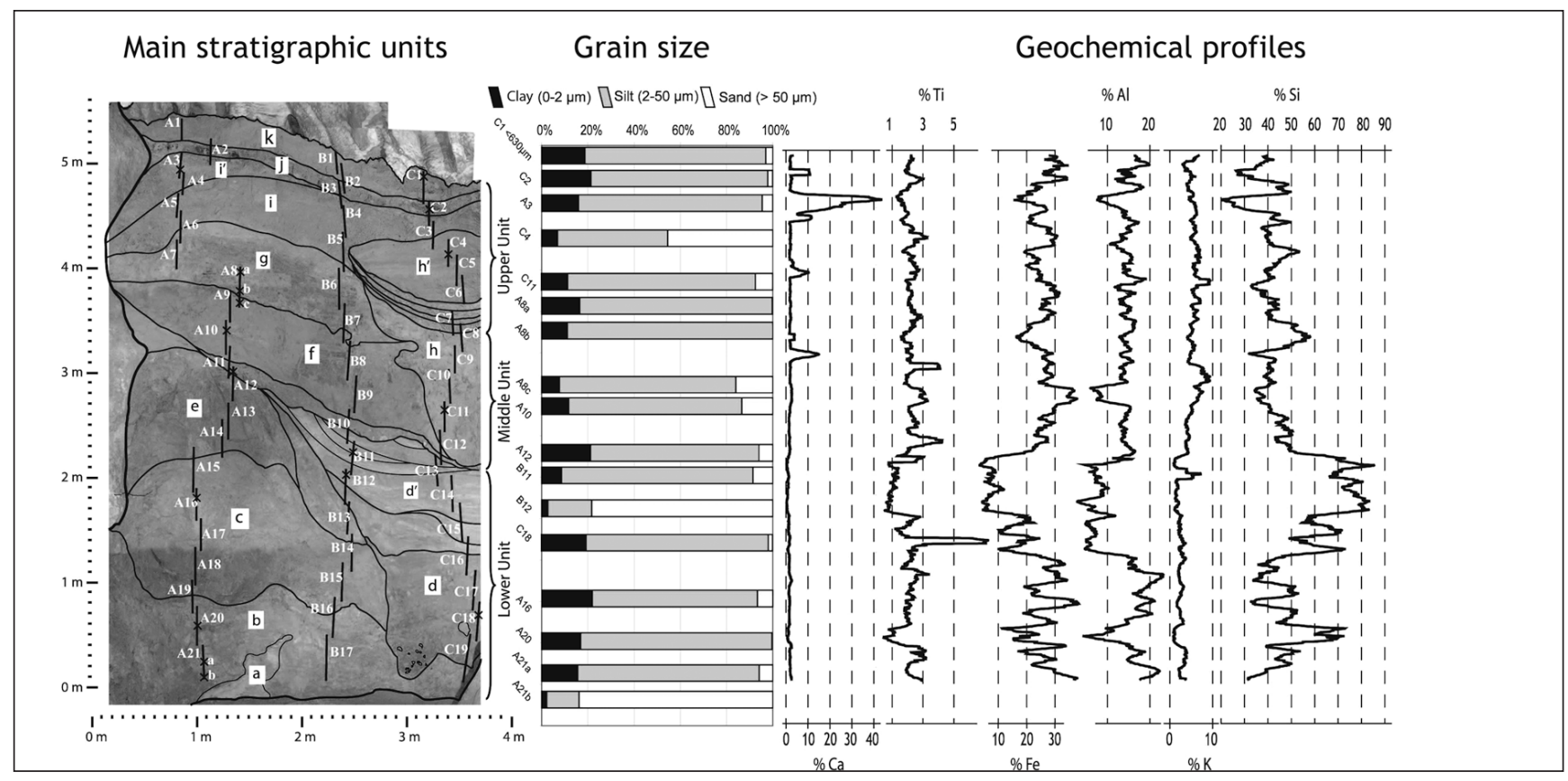

Fig. 11 - Geochemical profiles by micro-XRF of the detritic infillings within the Mud Room (Charente, France).

Fig. 11 - Profils géochimiques obtenus par micro-XRF du remplissage détritique de la salle de la Boue (Charente, France). 
section, the geochemical profile shows variations of very high magnitude, especially for the elements $\mathrm{Si}, \mathrm{Fe}$ and $\mathrm{Al}$. The lower layers, up to $2.5 \mathrm{~m}$, are characterised by extremely high levels of silicon $(\sim 60-65 \%)$ and lower concentrations of iron $(\sim 25-30 \%)$ and aluminium $(\sim 10-15 \%)$. Potassium and calcium are less than $2 \%$. Between 2.5 and $3.5 \mathrm{~m}$ high, Si increases sharply to represent a proportion of $\sim 93 \%$. $\mathrm{Fe}$ and $\mathrm{Al}$ decrease, while $\mathrm{K}$ and $\mathrm{Ca}$ remain constant. The upper half of the section shows a marked decrease in concentrations of $\mathrm{Si}$ and $\mathrm{Fe}$, whereas $\mathrm{Al}$ remains relatively constant. In contrast, the levels of $\mathrm{K}$ and $\mathrm{Ca}$ are higher, $\sim 6 \%$ and $3 \%$ respectively. The uppermost layers of the sedimentary sequence are characterised by peaks of $\mathrm{Ca}(>88 \%)$. In summary, occasionally high rates of $\mathrm{Fe}$ and $\mathrm{Ca}$, correlated with the grain-size analysis (Dandurand et al., 2010), are the chemical/mineralogical signatures of changes in the local environment marked by phases of coarse fluvial sedimentation. Conversely, $\mathrm{Al}$ and $\mathrm{K}$ further emphasise the phases of fine sedimentation related to the regional climate forcing characteristics of a temperate and very wet period of the Late Pleistocene (MIS 4). Si is present in both clay sedimentation and sandy channels, but in very different proportions. In conclusion, the comparison of micro-XRF data with other classical methods shows a good correlation, and validates geochemical analysis for palaeohydrological and palaeoclimate reconstructions.

\section{The monsoon rhythmites of Dadong Cave (China)}

Dadong Cave is a giant tunnel cave located in the central karst of China (Hubei province; fig. 12). The first studies and explorations showed two thick underground detrital sequences related to the monsoon floods: the 'Varves Rouges' (Middle or Lower Pleistocene; Maire, 1991) and the 'Varves Marrons' (Holocene; Pomel and Maire, 1995 and 1997; Delannoy et al., 2009). A remarkable site effect explains these

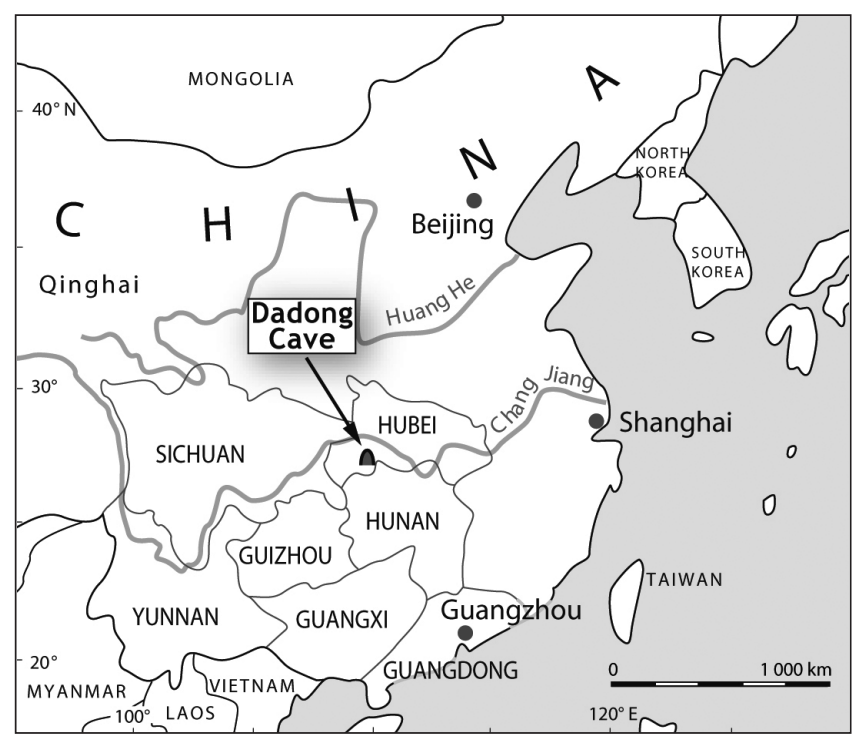

Fig. 12 - Location map of the Dadong giant cave (Hubei, China).

Fig. 12 - Carte de la localisation de la grotte géante de Dadong (Hubei, Chine). palaeohydroclimatic records: the cone karst of the middle mountain (900-2000 m), heavy monsoon rains, discharge between 0 and $50 \mathrm{~m}^{3} / \mathrm{s}$, subterranean piracy during the Pleistocene, a giant cave with large galleries and chambers, fluviatile terraces and thick rhythmite sequences in the lower part related to the proximity of the water table (formation of temporary lakes by excess water). A complete sampling was made on the 'Varves Marrons' sequence (12 m) by the method of U-shaped channels and a preparation with a shovel to get a series of steps. In the laboratory, the three geochemical methods were used: a portable XRF analyser, an XRF core scanner and a zoom with micro-XRF. The first method with the portable Niton (1 measurement every $20 \mathrm{~mm}$ for the first metre) provides a first indication of the evolution of the main elements, such as $\mathrm{Fe}$ and $\mathrm{Mn}$, and the secondary elements, such as $\mathrm{Ti}$ and $\mathrm{Rb}$. The second method with the core scanner has the advantage of providing a more detailed diagram ( 1 point every $1 \mathrm{~mm}$, time $10 \mathrm{~s}, 12000$ measurements). The third method with micro-XRF (1 point every $100 \mu \mathrm{m}$ ) can follow the chemical evolution at the scale of the smallest lamina. However, because of the precision and long measurement time (300 s/point), we focus only on the most interesting parts (work in progress). A first synthetic diagram was made for $\mathrm{Fe}$ and $\mathrm{Mn}$ with a portable analyser (fig. 13). The changes in Fe throughout the sequence show several interesting signals: peaks related to the erosion of red soils at the bottom (Cal BP 14040-13820 on charcoal), variations in grey and red laminated layers between $1 \mathrm{~m}$ and $6 \mathrm{~m}$, a lower signal between $8 \mathrm{~m}$ and $10 \mathrm{~m}$ (brown silt sedimentation), and a strong signal at the top because of the recent anthropic erosion during the last two centuries (Cal BP 220-140). A zoom of $119 \mathrm{~cm}$ was made between $413 \mathrm{~cm}$ and $532 \mathrm{~cm}$ at the beginning of the Holocene $\left({ }^{14} \mathrm{C}\right.$ date at $340 \mathrm{~cm}$ on charcoal: 10760-10680 cal. BP). The diagram shows the detailed changes in $\mathrm{Fe}, \mathrm{Si}, \mathrm{K}, \mathrm{Al}$, and $\mathrm{Mn}$ (fig. 14). The regular distribution of $\mathrm{Al}$ is typical of clay minerals in silt. Some peaks $(\mathrm{Fe}, \mathrm{Si})$, however, are related to variations in grain size analysis and to red areas rich in $\mathrm{Fe}_{2} \mathrm{O}_{3}$ in D27, D26, and the bottom of D23. The distribution of $\mathrm{Fe}$ and $\mathrm{Si}$ is uniform in the large grey strata of D25. Mn is concentrated in the red layers (D27, D26, D23). The signals are sometimes disrupted by artefacts such as desiccation cracks and irregular surfaces. The next step will be to study the precise distribution of the main elements throughout the sequence to show the hydroclimatic signal with some high resolution chemical imaging and a comparison with micromorphological studies on thin sections (work in progress, 'Climanthrope' programme).

\section{Measurements on ice and prehistoric paintings in caves}

Geochemical analysis of underground snow and ice: example of Scarasson Cave (Marguareis, Italy) Micro-XRF

Three explorations between 2007 (Maire et al., 2009d) and 2010 focused on the evolution of the cave glacier of Scarasson (Marguareis, Italy; fig. 3). The speleological ob- 


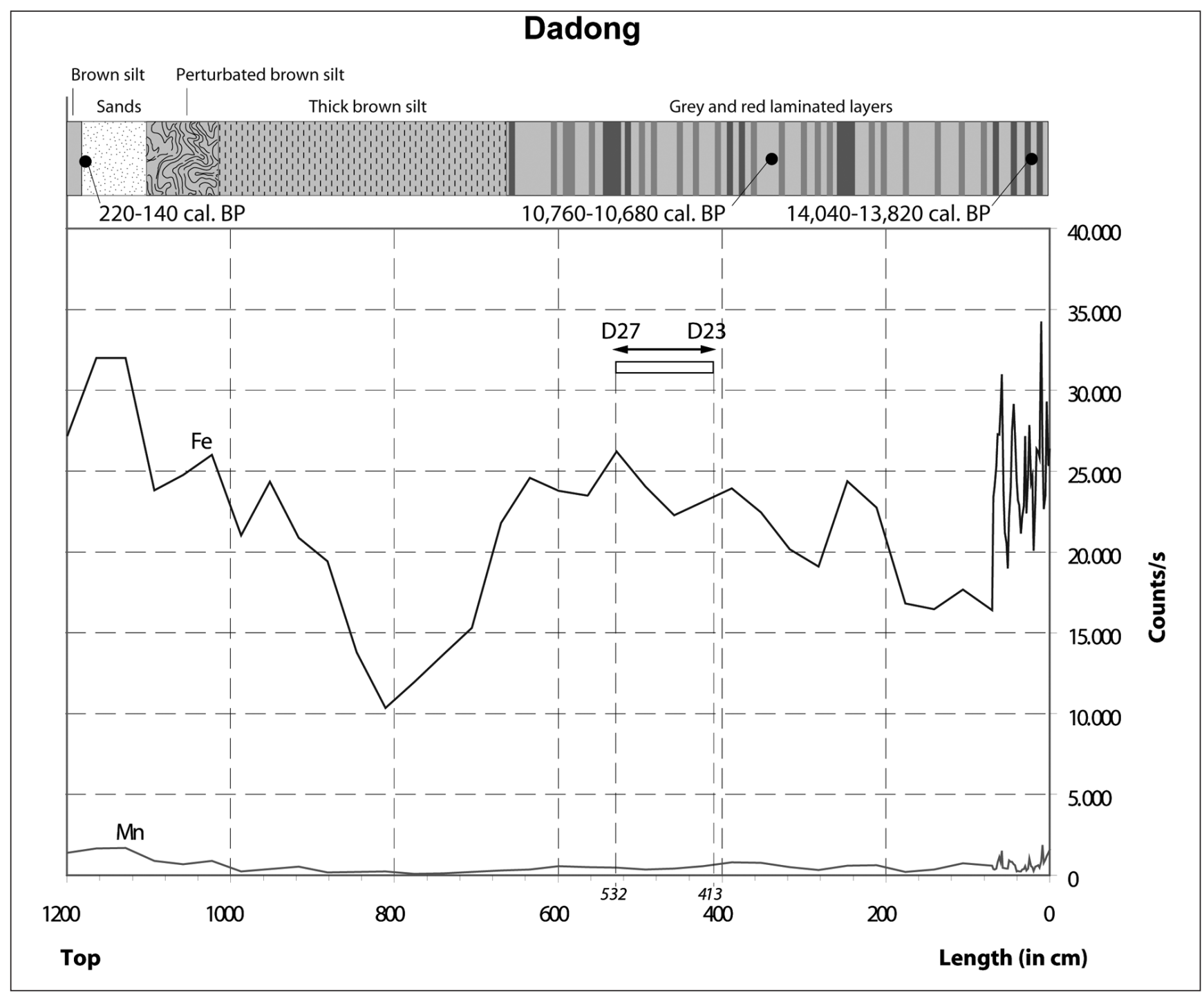

Fig. 13 - Reconnaissance geochemical diagram for the Dadong sequence (Fe-Mn) made with a micro-XRF portable analyser (Hubei, China).

Fig. 13 - Diagramme géochimique préliminaire de la séquence détritique de Dadong (Fe-Mn) à partir d'un micro-XRF portatif (Hubei, Chine).

servations highlight an accelerated melting of the glacier of Scarasson in recent years. The scientific goal of these investigations is to quantify the melting and explain its origin: the possible effect of global warming, changes in underground ventilation, obstruction of a higher snow pit (fig. 15). The results are very preliminary but give a good idea of the potential use of this method. The answer is not yet definitive, but the geochemical characterisation of micro-dark debris in the ice at different levels of the underground glacier has led to some initial answers. The micro-XRF analyses carried out on the fine fraction of these micro-dark debris (tab. 3) show a predominance of the following: calcium $(66.3 \%)$, silicon $(15.2 \%)$, iron (9\%), aluminium $(5.2 \%)$ and potassium $(2 \%)$. The bottom of the glacier contains $82 \%$ calcium, as limestone. Micro-black debris, in addition to organic matter and plant debris, also contains residues of soils with the classic association of clay and iron hydroxides. In contrast, the uppermost and middle parts of the glacier are enriched in $\mathrm{Al}$, $\mathrm{Si}, \mathrm{K}, \mathrm{Ti}$ and $\mathrm{Fe}$ to the detriment of $\mathrm{Ca}$. Thus, layers of ice have more trapped debris like alumina silicate, mica, aeolian quartz grains and other hydroxides confirmed by micromorphological observations. The recent snow located at $-53 \mathrm{~m}$ above shows higher percentages of $\mathrm{Al}(>11 \%)$, Si $(>37 \%)$, and $\mathrm{K}(>5 \%)$ than those recorded in the glacier. Thus, the source of this allochtone debris has varied. Meanwhile, from the benchmark of the old floor of ice, discovered by Michel Siffre in 1962, the laser distance metre measurements showed a decrease of $1 \mathrm{~m}$ from the glacier in 47 years with $25 \mathrm{~cm}$ between August 2008 and August 2009. The recording of the surface temperature of the ice mass has confirmed this decline by showing that it is a temperate ice, very near the melting point $\left(-0.03^{\circ} \mathrm{C}\right.$ to $-5 \mathrm{~cm}$ and $-0.06^{\circ} \mathrm{C}$ to $\left.-20 \mathrm{~cm}\right)$. The glacier is melting at great speed, which explains the recrystallisation and the rise of air bubbles in the form of beads. This phenomenon is due to melting of the base of the glacier at the summit (Maire et al., 2009d). The geochemical analyses coupled with other methods illustrate the fact that recent increases in temperature impact on the disequi- 


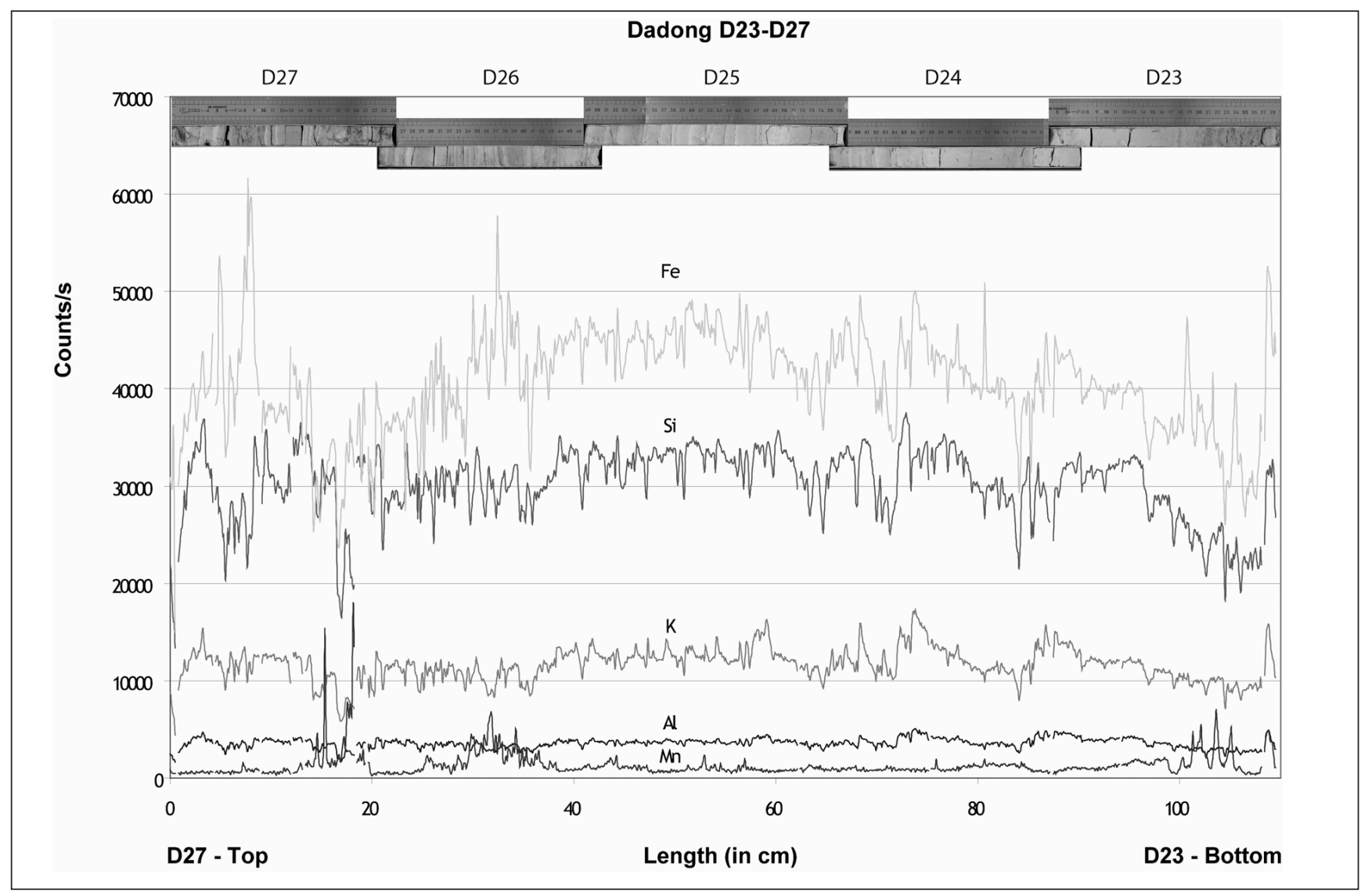

Fig. 14 - Geochemical diagram by XRF Core scanner for the Dadong sequence (Hubei, China). Zoom on section $413-532 \mathrm{~cm}$ (Fe-Si$\mathrm{K}-\mathrm{Al}-\mathrm{Mn})$.

Fig. 14 - Diagramme géochimique obtenu par Core scanner pour la séquence détritique de Dagong (Hubei, Chine). Zoom sur la section 413-532 cm (Fe-Si-K-Al-Mn).

\begin{tabular}{|c|c|c|c|c|c|c|c|c|c|c|c|c|c|c|c|}
\hline Number & Spectrum label & $\begin{array}{c}\text { Profondeur } \\
\text { (in } \mathbf{m} \text { ) }\end{array}$ & $\mathbf{A l}$ & $\mathbf{S i}$ & $\mathbf{P}$ & $\mathbf{S}$ & $\mathbf{K}$ & $\mathbf{C a}$ & $\mathbf{T i}$ & $\mathbf{M n}$ & $\mathbf{F e}$ & $\mathbf{Z n}$ & $\mathbf{R b}$ & $\mathbf{S r}$ & $\mathbf{T o t a l}$ \\
\hline 1 & Névé & -53 & 11.25 & 37.36 & 1.00 & 0.24 & 5.53 & 20.33 & 1.63 & 0.70 & 21.34 & 0.37 & 0.16 & 0.09 & 100 \\
\hline 2 & Top & -100 & 6.52 & 17.05 & 0.32 & 0.07 & 2.58 & 62.4 & 1.20 & 0.40 & 9.17 & 0.07 & 0.04 & 0.18 & 100 \\
\hline 3 & Middle & -102 & 5.84 & 17.42 & 0.57 & 0.12 & 2.49 & 58.77 & 0.89 & 0.64 & 12.85 & 0.25 & 0.06 & 0.10 & 100 \\
\hline 4 & White layer & -110 & 5.68 & 16.89 & 0.46 & 0.04 & 1.88 & 61.62 & 0.76 & 1.76 & 10.65 & 0.04 & 0.1 & 0.12 & 100 \\
\hline 5 & Bottom glacier & -125 & 2.93 & 9.59 & 0.25 & 0.05 & 0.89 & 82.38 & 0.30 & 0.17 & 3.18 & 0.08 & 0.01 & 0.17 & 100 \\
\hline & Average & - & 5.24 & 15.24 & 0.40 & 0.07 & 1.96 & 66.29 & 0.79 & 0.74 & 8.96 & 0.11 & 0.05 & 0.14 & - \\
\hline
\end{tabular}

Result type: mass (in \%).

Tab. 3 - XRF results for the subterranean glacier of Scarasson, Marguareis, Italy (dusts and micro-debris).

Tab. 3 - Résultats des analyses XRF du glacier souterrain de Scarasson, Marguareis, Italie (poussières et micro-débris).

librium of the subterranean glacier and modify the origin of the materials trapped in the ice layers.

Example of a Pacific prehistoric cave (Patagonia, Chile) - Portable X-ray unit

Located between $50^{\circ} \mathrm{S}$ and $51^{\circ} \mathrm{S}$ in a subpolar region, the Madre de Dios archipelago (fig. 16) is an outstanding natural and archaeological heritage site, which Chile designated a protected area in 2008. It is one of the most hostile lands of the planet, perpetually flooded by heavy rain $(7-8 \mathrm{~m} / \mathrm{a})$ and battered by strong winds. Since 2000, the FrenchChilean speleological expeditions have revealed many exceptional coastal caves. Discovered in 2006, Pacific Cave (fig. 17) is the first archaeological cave found in the Patagonian islands containing paintings from the Kawésqar culture (Jaillet et al., 2009). The Alakalufs (or Kawésqars) have 


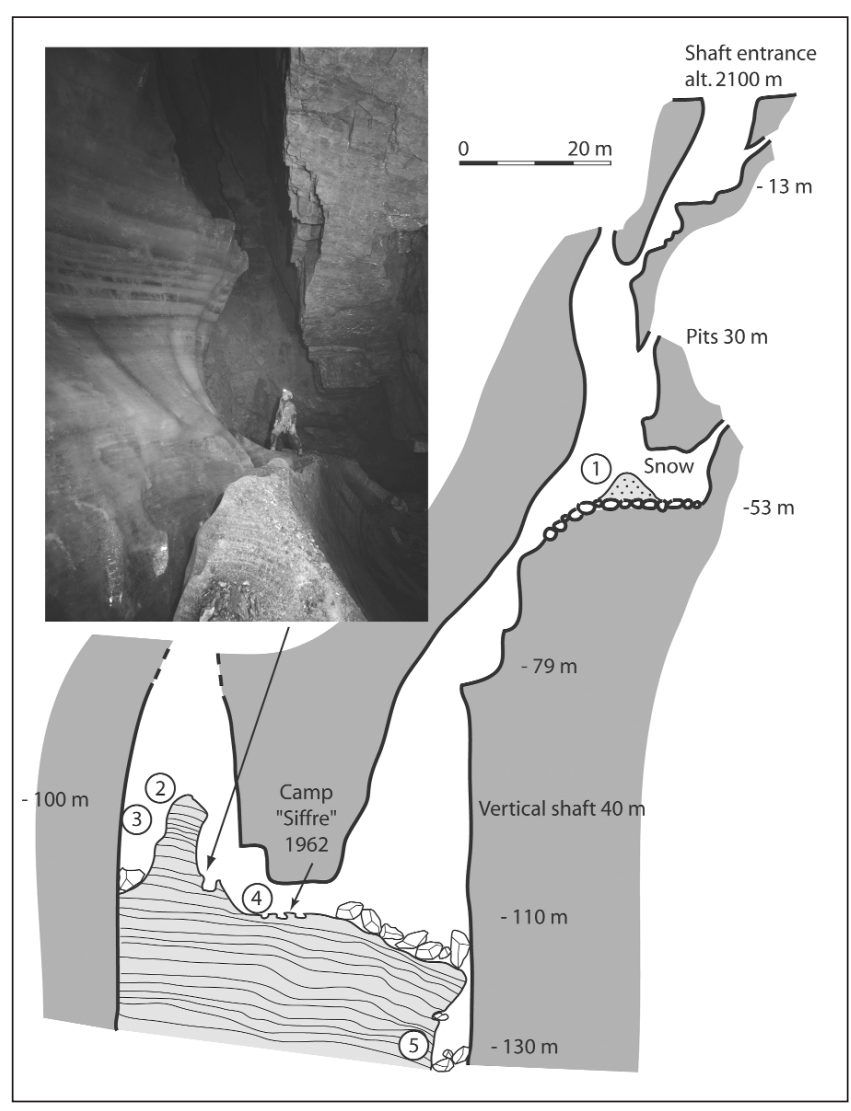

Fig. 15 - Section of Scarasson Cave with its subterranean glacier (Southern Alps, Italy; photo: Serge Caillault, 2009).

Fig. 15 - Coupe de la grotte de Scarasson et du glacier souterrain (Alpes du Sud, Italie ; photo: Serge Caillault, 2009).

lived as nomads of the sea for 6000 years. Victims of European diseases during the last centuries, there are now only sixteen survivors, gathered together in Puerto Eden, north of the archipelago. This marine cave, $3 \mathrm{~m}$ above present sea level, contains thick shelly deposits (limpets), bone fragments, fireplaces with charcoal and 50 paintings, including 30 of red ochre and 20 of charcoal (fig. 17). Several non-destructive analyses (tab. 4) with a portable X-ray unit (Niton) confirmed that the red ochre paintings, at the bottom of the cave, are rich in iron oxide, $\mathrm{Fe}_{2} \mathrm{O}_{3}(\mathrm{Fe}=10900 \pm 400 \mu \mathrm{g} / \mathrm{g}$ to $27000 \pm 600 \mu \mathrm{g} / \mathrm{g}$ ). The charcoal paintings contain $1230 \mu \mathrm{g} / \mathrm{g}$ to $1630 \pm 30 \mu \mathrm{g} / \mathrm{g}$ of $\mathrm{Sr}$. By comparison, the $\mathrm{Sr}$ content in

\begin{tabular}{|c|c|c|c|c|c|}
\hline Sample & Time (in s) & $\mathbf{S r}$ (in ppm) & $\mathbf{P b}$ (in ppm) & Ni (in ppm) & Fe (in ppm) \\
\hline Painting 1 & 120 & $147.4 \pm 9.5$ & $33.3 \pm 16.9$ & $112.1 \pm 60.7$ & $16300 \pm 400$ \\
\hline Painting 2 & 120 & $128.1 \pm 8.8$ & $33.7 \pm 15.9$ & $95.2 \pm 55.8$ & $18500 \pm 400$ \\
\hline
\end{tabular}

Tab. 4 - Chemical analysis of paintings in the Pacific Cave (Patagonia, Chile).

Tab. 4 - Résultats des analyses XRF des peintures rupestres de la grotte du Pacifique (Patagonie, Chili).

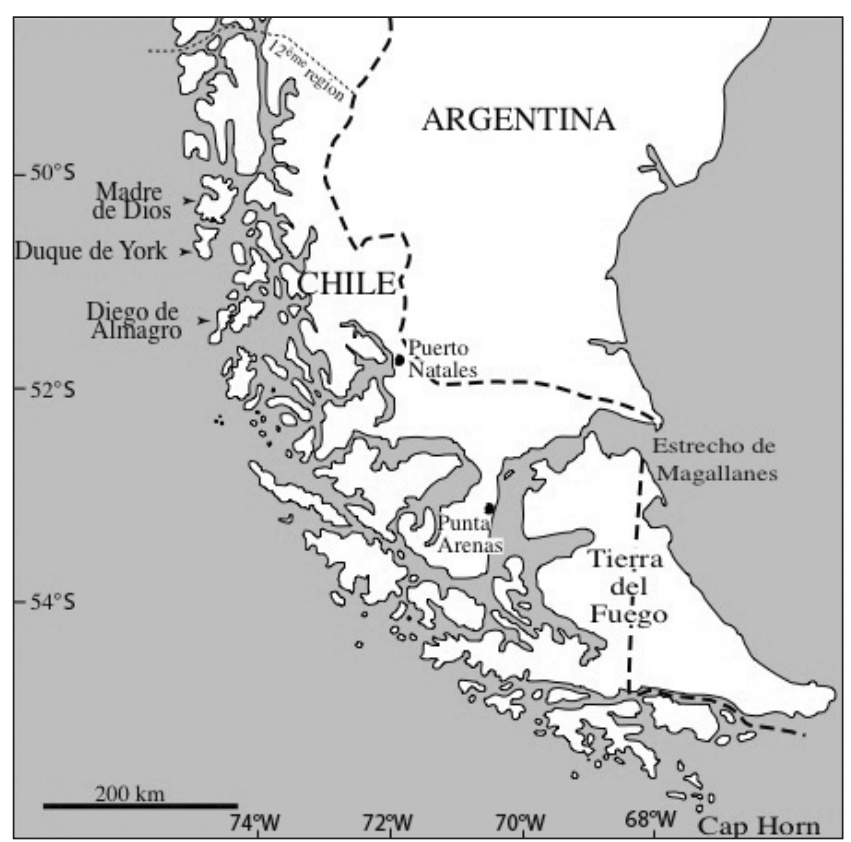

Fig. 16 - Location map of Madre de Dios (Patagonia, Chile).

Fig. 16 - Carte de localisation de l'île de Madre de Dios (Patagonie, Chili).

the Permian limestone is $200-400 \pm 10 \mu \mathrm{g} / \mathrm{g}$ and in ochre $120-140 \pm 9 \mu \mathrm{g} / \mathrm{g}$. Because of the marine origin of the Pacific cave and its low altitude $(+3 \mathrm{~m})$, its occupation cannot be older than the last few millennia because of the recent glacio-isostatic level dated at 3000 years in the marine cemetery of Whale Cave (two ${ }^{14} \mathrm{C}$ dates on whale bones; Maire et al., 2009c). All these karst and archaeological features recorded in littoral caves provide an understanding of the complex evolution of this coastal area since the last deglaciation and the origin of Kawésqar occupation.

\section{Discussion}

Importance of the site effect (tab. 1 and fig. 18)

It is commonly agreed that detrital deposits are a response to variations in the hydrosedimentary dynamics, themselves related to fluctuations in both regional and local palaeoclimatic and palaeoenvironmental parameters. One of the objectives of the "Climanthrope" ANR programme is to characterise relationships between the site and deep subterranean deposits. Geochemical analyses in combined studies with grain-size analyses, mineralogical and micromorphological analyses provide a good discrimination of both the role of the morphology of the site and the karsto-speleogenesis context (geometry, cave size, position in the cave, lithology, speleogenesis and formation of galleries and rooms, palaeoflows, floods and fluctuations in the water table position, subterranean microclimate, type of vege- 


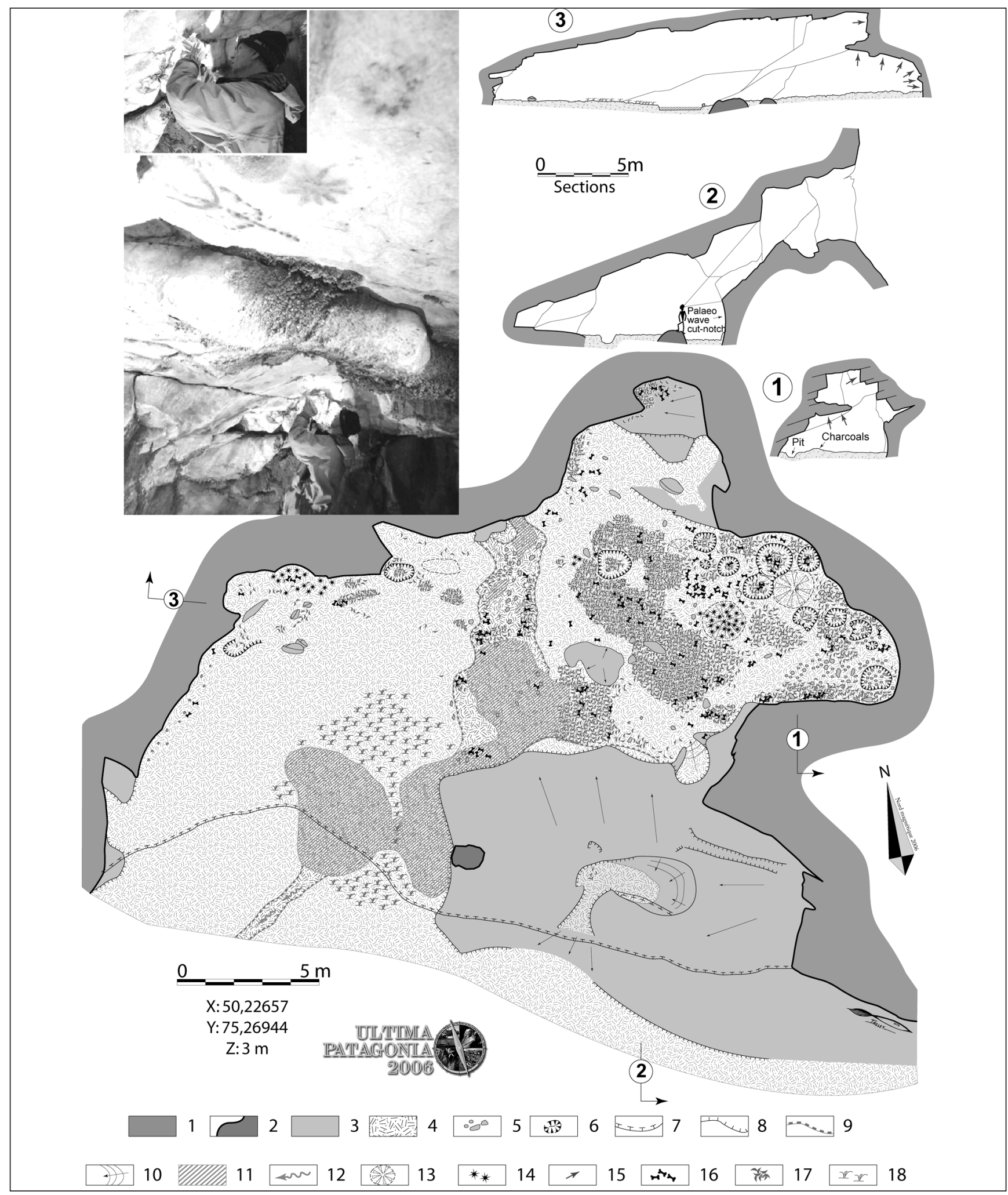

Fig. 17 - Map of the Pacific Cave (Patagonia, Chile). Paintings are located in the back showing the use of the cave as a shelter. Use of an XRF portable analyser on ochre paintings in Pacific Cave; 1 : limestone; 2: limestone wall; 3: limestone outcrop; 4: clayey silt deposit; 5: blocks; 6: pit; 7: topographic step ceiling; 8: topographic step floor; 9: fluvial depression; 10: slope; 11: water; 12: flow; 13: topographic apex; 14: charcoals; 15: cave paintings (sections); 16: bones; 17: shell mounds; 18: hydrophilic vegetation (from Jaillet et al., 2009, modified).

Fig. 17 - Plan de la grotte du Pacifique (Patagonie, Chili). Les peintures se situent au fond de la cavité, qui a joué un rôle d'abri pour les populations locales. Utilisation d'un micro-XRF portatif pour analyser les peintures à l'ocre. $1:$ calcaire; $2:$ paroi calcaire ; $3:$ calcaire affleurant ; 4 : sol argilo-limoneux ; 5 : blocs calcaires ; $6:$ fosse ; $7:$ seuil topographique au plafond ; $8:$ seuil topographique au sol ; $9:$ entaille fluviatile du remplissage ; 10 : pente topographique ; 11 : eau ; 12 : écoulement d'eau ; 13 : apex topographique ; $14:$ charbons ; 15 : peintures pariétales (coupes) ; 16 : ossements ; 17 : amas coquiller ; 18 : végétation hydrophile (d'après Jaillet et al., 2009, modifiée). 


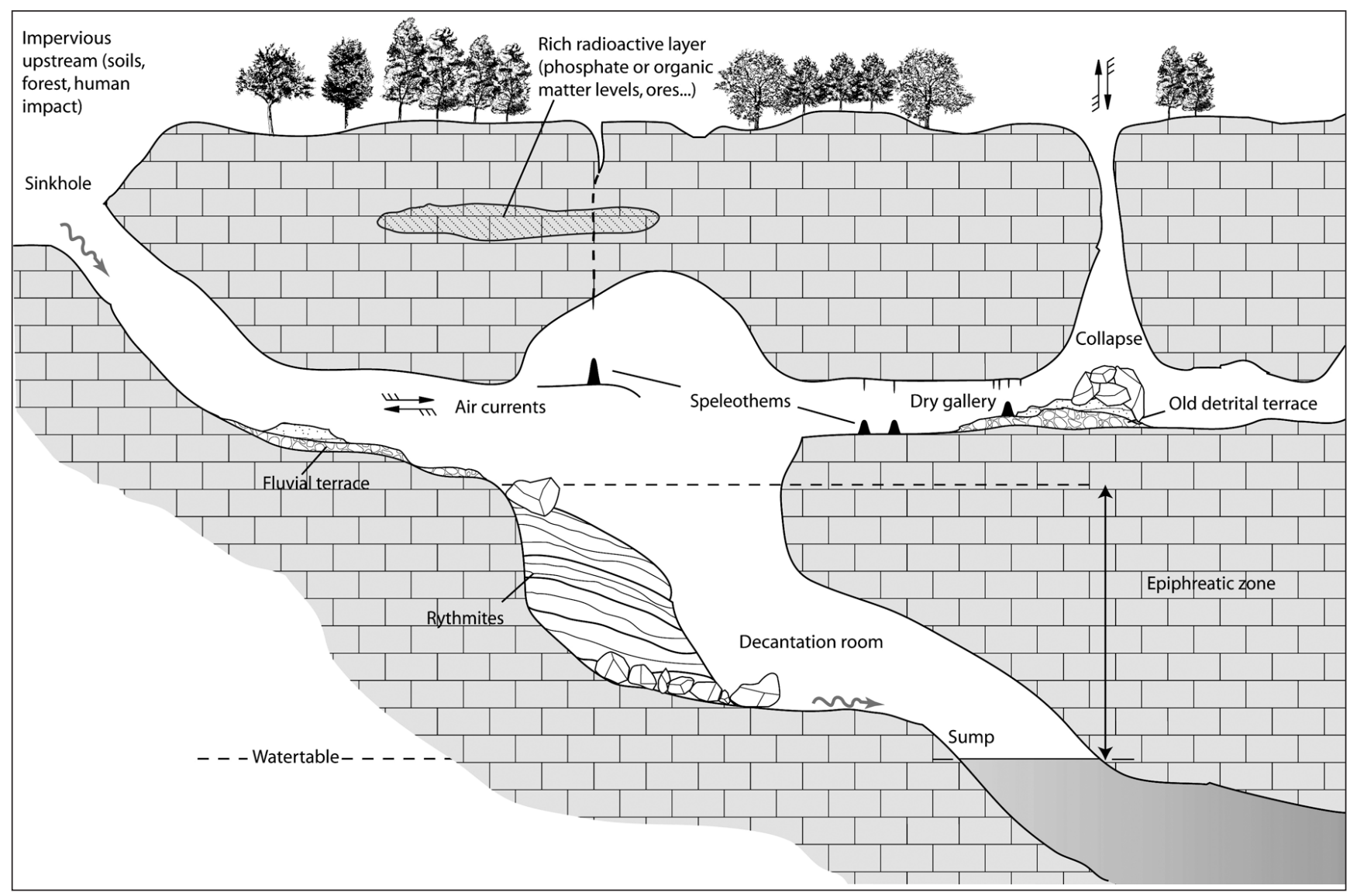

Fig. 18 - Types of favourable site in caves for palaeoenvironmental records, especially a decantation room for rhythmites (in the epiphreatic zone) and a dry gallery for speleothem growth. Examples of sites 1, 2, 4, and 5.

Fig. 18 - Types de sites favorables à l'enregistrement paléoenvironnemental en grotte, particulièrement pour les rythmites des salles de décantation (dans la zone épiphréatique) et pour la croissance des spéléothèmes dans les galeries fossiles. Exemples des sites 1, 2, 4 et 5 .

tation and soils, human impact) directly on the hydrosedimentary dynamics and indirectly on the recording of the palaeoclimatic and palaeoenvironmental signals (Darrénougué et al., 2009; Cuven, 2009). The seven studied examples show several proxy environmental records: speleothems in natural and artificial caves, detrital rhythmites, stratified subterranean ice and prehistoric parietal paintings. Each proxy, with typical chemical signals, depends on a favourable site effect such as:

- Site 1: dry gallery protected from erosion and good microclimatic site (strong evaporation) for the 'radioactive terrace' of Pierre Saint-Martin (Pyrenees, France);

- Site 2: active gallery with speleothems contaminated by floods and turbid percolation (with zircon grains) in the low plateau of Entre-deux-Mers (Gironde, France);

- Site 3: artificial tunnel under Lyon city favourable for recording anthropic pollution like sulphur;

- Site 4: underground chamber as a decantation place for fluvial and karst water table sedimentation in the low plateau of Charente (France);

- Site 5: large subterranean chamber located $80 \mathrm{~m}$ above the saturated zone (sump). During the big monsoon floods (> $20 \mathrm{~m}^{3} / \mathrm{s}$ ), the room becomes a decantation lake;
- Site 6: high mountain vertical cave with a bottom room $(-100 \mathrm{~m})$ as a trap for snow and cold air ('glacière');

- Site 7: coastal cave as a shelter for Kawésqar people and showing thick shelly deposits and parietal paintings.

The comparison of different study sites helps to demonstrate the varying effects from one site to another, first in terms of trapping detrital sedimentary material or carbonates (accumulation/erosion) associated with the hydrosedimentary dynamics, and secondly in terms of filtering (amplification/attenuation) palaeoclimatic and palaeoenvironmental signals. Moreover, this comparison of different sites located in very different morpho-climatic contexts has highlighted the importance of the following points: the position of the deposits in the cave, the geometry of the cave, the cave genesis, the lithology features, the subterranean microclimate, past and recent human activities.

To summarise: (i) Palaeoenvironmental and palaeoclimate information tends to be attenuated in the deep subterranean karst, while deposits of cave entrances (porches and rockshelters) appear more sensitive to the effects of climate forcing; (ii) Near the cave entrances or in a shallow endokarstic context, the palaeoenvironmental and palaeoclimate signals tend to be confused with the anthropogenic signals (fires, de- 
forestation, industry, traffic) which cause an artificial enrichment of some chemical elements $(\mathrm{S}, \mathrm{Cu}, \mathrm{Zn})$ in the studied deposits; (iii) Deep in the karst, the biggest rooms enable a complex accumulation of large amounts of sediment of different types (fluviatile sediments, decantation, collapses, debris flow, monsoon floods) whereas the shafts are not favourable for these accumulations. Ice, whose mechanical and chemical properties allow significant vertical accumulation, is the only exception; (iv) The cave genesis plays a major role; the hydrosedimentary signatures will vary considerably from one site to another depending on whether it is a rapid or slow formation, if the speleogenesis is mainly controlled by fluctuations in the water table, or if the formation is basically paragenetic, epigenetic, or hypogene of ghostrock formation; (v) Signals can be modified by the nature of the rock. This happens when the rocks are locally enriched in uranium or thorium which has a direct effect on the availability of radiometric U/Th dating; (vi) The subterranean microclimate can be a limitation for the preservation of sediments (diagenesis phenomenon, modification of the physicochemical properties of the sediments due to fluctuations in the temperature and humidity content).

\section{Characterisation of palaeoclimatic and palaeoenvironmental conditions}

In several sites, speleothems and detrital cave sediments contain evidence of changes in hydro-climatic conditions and specific forcing factors (Perroux et al., 2010). In addition, they give good information about local conditions and reveal the major influence of the site because of geomorphic factors. The example of karst deposits in Charente shows high Fe contents, closely associated with silts and fluvial deposits. This characterises temperate and very wet conditions. Conversely, $\mathrm{Al}$ and $\mathrm{K}$ values reveal a low deposition related to colder and drier conditions. High $\mathrm{Ca}$ values reflect the $\mathrm{CaCO}_{3}$ content of the sediment, which is partly derived from pebbles and collapsed blocks. Si is present in both the clay sedimentation and the fluvial quartz, but in very different proportions. For speleothems and historic detrital deposits, a new direction consists in identifying some typical layers as volcanic ashes (e.g., the eruptions of Santorini: 1650 BC; Tambora: AD 1815; Krakatau: AD 1883; Frisia et al., 2008; Siklosy et al., 2009). The underground glacier of Scarasson in the Southern Alps (Italy) highlights the recent changes in climate (global warming) and the modification of several parameters which control the site effect, for example changes in air circulation in the cave and the stopping of snow feeding into the lower part of the cave for several decades. The first geochemical analyses indicate a clear difference between the impurities of recent snow and the impurities of old ice.

\section{Characterisation of anthropogenic signals}

The speleothem extracted from a tunnel under Lyon is a remarkable environmental record of industrial and urban growth during the 20th century. The high content of $\mathrm{S}, \mathrm{Cu}$ and $\mathrm{Zn}$ are very likely anthropogenic. Another analysis on the right part of the speleothem indicates that Ti can reach locally a high content of $20000 \mu \mathrm{g} / \mathrm{g}$. Here Ti is also an indicator of pollution, probably by titanium oxide (found in paint, plastic, synthetic rubber and ceramics). A dual study using chemical imaging and micromorphology on thin sections is indispensable to understand the influence of crystal growth and diagenesis, and to discover other phenomena (e.g., light amorphous silicification on the top). These anthropogenic samples are very useful to study the effects of human impacts on the urban environment for several centuries, such as in the catacombs of Paris and in many artificial tunnels. The chemical identification of cave paintings discovered on Madre de Dios Island (Patagonia) shows high $\mathrm{Fe}$ values in relation to ochre. This non-destructive method with a portable XRF analyser is very useful for geoarchaeology, especially if the artefacts are thin, fragile and impossible to sample. This field method is also very practical to measure quickly the inorganic chemical composition of many samples of natural and artificial origin.

\section{Identification of radioactive levels and implication for radiometric dating}

The mapping of chemical elements is a fundamental and powerful technique for understanding the phenomena of diagenesis in speleothems (Ortega et al., 2010). The radioactivity imaging in the speleothem by Beta Imager, micro-XRF and microprobe is another tool to understand the origin of this diagenesis better and to evaluate the radiometric dating. The maximum content of $\mathrm{U}$ measured in a natural concretion is $1200 \mu \mathrm{g} / \mathrm{g}$ in a corallite speleothem from the Baikal area; it is due to a replacement of aragonite by uraniferous opal probably after volcanic contamination (Maire et al., 2009a). In the Pyrenees and Gironde, the high content of $\mathrm{U}(300 \mu \mathrm{g} / \mathrm{g})$ or Th $(280 \mu \mathrm{g} / \mathrm{g})$ disturbs the recording of the palaeoenvironmental signal. In addition, there are consequences for the U/Th or $\mathrm{U} / \mathrm{Pb}$ dating of ancient carbonates. A number of dates considered trustworthy in the current state of knowledge are likely to be re-evaluated. The high radioactivity can be explained by the percolation water that washes through some rich radioactive layers (phosphatic beds, organic matter and algae levels, palaeokarsts, ores) or by external contamination (volcanic ash, human pollution). Thus, although the geochemical analysis of speleothems does not provide all the answers, it can raise new issues in relation to the geomorphology.

\section{Conclusions}

Today, palaeoclimatology uses many proxy records of marine and continental origin, especially the signal of stable isotopes $\left(\delta^{13} \mathrm{C}\right.$ and $\left.\delta^{18} \mathrm{O}\right)$ in speleothems and marine cores, and $\mathrm{CO}_{2}$ content, $\mathrm{H}$ and $\mathrm{O}$ isotopes in polar ice. Geochemical analysis in the multi-proxy records in caves also represents an important direction for geomorphological and palaeoenvionmental studies. The high variability of geochemical signals recorded in carbonate and detrital sediments protected 
in some favourable subterranean sites is related to local and regional parameters following the site effect: regional climate, altitude, cave physiognomy, wall geometry, location of the water table, underground microclimate, catchment characteristics, human impacts, etc. Many kinds of cave sediment and material can be characterised: alluvial deposits, speleothems, ore deposits, palaeokarsts, dusts, parietal paintings and crusts. Geochemical imagery and analysis have to be used with the other classical methods. Micromorphology/petrography on thin sections coupled with other macroand microscopic techniques (laser analysis, epifluorescence, cathodoluminescence, electron microscope) and microchemical imagery are powerful tools for understanding diagenesis and crystallochemical processes, especially for aragonitecalcite-silica concretions. For fine alluvial sediments, micrograin size techniques, lithostratigraphy and geochemical profiles highlight the variability and origin of minerals and the different kinds of sedimentation and run-off. Because karst phenomena are present almost everywhere on earth, in different latitudes and geographical situations (coastal, plain, plateau, mountain environments), important perspectives of research can be widened to geosciences, palaeoclimatology, archaeology, palaeoenvironment and human impact studies.

\section{Acknowledgements}

This paper is a synthesis of several years of research. The authors would like to acknowledge several colleagues: S. Caillault, M. Siffre, J.-J. Delannoy, D. Genty, I. Couchoud, L.-H. Fage for their stimulating speleological and geomorphological discussions. Field investigations was supported by the CNRS, ANR "Climanthrope », the Club Martel (Scarasson), the Association Centre Terre group (Patagonia), the Association de Recherches Spéléologiques group (Charente), Thanks are also due to P. Forti, G. Arnaud-Fassetta and three other anonymous reviewers for their constructive and fruitful discussions. Finally we thank C. Robins for correction and improvement of the original English manuscript.

\section{References}

Alvinerie J. (1969) - Contribution sédimentologique à la connaissance du Miocène aquitain. Interprétation stratigraphique et paléogéographique. Thèse d'État, université de Bordeaux, $475 \mathrm{p}$.

Bariand P., Cesbron F., Geffroy J. (1984) - Les minéraux. Leurs gisements, leurs associations. Éditions du BRGM, Paris, 3 t., 928 p.

Barthe N. (2007) - L'imagerie bêta haute résolution. Médecine Nucléaire, 31, 193-201.

Böning P., Bard E., Rose J. (2007) - Toward direct, micron-scale XRF elemental maps and quantitative profiles of wet sediments. Geochemistry, Geophysics, Geosystems 8-5, 1-14.

Cole J.M., Nienstedt J., Spataro G., Rasbury E.T., Lanzirotti A., Celestian A.J., Nilsson M., Hanson G.N. (2003) - Phosphor imagery as a tool for in situ mapping of ppm levels of uranium and thorium in rocks and minerals. Chemical Geology 193, 127-136.

Cuven S. (2009) - Validation and use of the micro X-ray fluorescence to characterize clastic varves and paleoclimate quantifi- cation of the late Holocene in the Canadian High Arctic. Published Ph.D. Thesis in Earth Sciences, INRS-ETE, université du Québec, 332 p.

Dandurand G., Maire R., Devès G., Perroux A.-S., Ghaleb B., Ortega R. (2010) - La série détritique de la grotte du Bois du Clos (Charente, France). Mise en évidence d'une paléo-hydrologie de stade froid et humide et rôle de l'effet de site. In Vanara N., Douat M. (Eds.) : Le karst, indicateur performant des environnements passés et actuels. Karstologia Mémoires, 17, 152-162.

Darrénougué N., De Decker P., Fitzsimmons K.E, Norman M.D., Reed L., van der Kaars S., Fallon S. (2009) - A late Pleistocene record of aeolian sedimentation in Blanche Cave, Naracoorte, South Australia. Quaternary Science Reviews 28, 2600-2615.

Delannoy J.-J., Gauchon C., Hoblea F., Jaillet S., Maire R., Perrette Y., Perroux, A.-S., Ployon E., Vanara N. (2009) - Karst : from palaeogeographic archives to environmental indicators. Géomorphologie : relief, processus, environnement 2, 83-94.

Fairchild I.J., Smith C.L., Baker A., Fuller L., Spötl C., Mattey D., McDermott F., EIMF. (2006) - Modification and preservation of environmental signals in speleothems. Earth-Science Reviews 75, 105-153.

Frisia S., Borsato A., Faichild I.J., Susini J. (2005) - Variations in atmospheric sulphate recorded in stalagmites by synchrotron micro-XRF and XANES analyses. Earth and Planetary Science Letters 235, 729-740.

Frisia S., Badertscher S., Borsato A., Susini J., Göktürk O.M., Cheng H., Edwards R.L., Kramers J., Tüysüz O., Fleitmann D. (2008) - The use of stalagmite geochemistry to detect past volcanic eruptions and their environmental impacts. PAGES News, 16, 3, 25-26 (http://www.pages-igbp.org/products/newsletters/ref2008_3.html visited 30 July 2010).

Genty D. (2002) - Spéléothèmes et paléoenvironements. In Miskovski J.-C. (Ed.) : Géologie de la Préhistoire: méthodes, techniques, applications. Association pour l'étude de l'environnement géologique de la préhistoire, Paris, 1345-1362.

Jaillet S., Fage L.-H., Maire R., Tourte B. (2009) - Découverte d'une grotte ornée dans l'archipel de Patagonie chilienne: la grotte du Pacifique. Spelunca Mémoires, 34, 173-183.

Katsuta N., Takano M., Kawakami S., Togami S., Fukusawa H., Kumazawa M., Yasuda Y. (2007) - Advanced micro-XRF method to separate sedimentary rhythms and event layers in sediments: its application to lacustrine sediment from Lake Suigestu, Japan. Journal of Paleolimnology 37, 259-271.

Kido Y., Koshikawa T., Tada R. (2006) - Rapid and quantitative major element analysis method for wet fine-grained sediments using an XRF microscanner. Marine Geology 229, 209-225.

Koshikawa T., Kido Y., Tada R. (2003) - High-resolution rapid elemental analysis using an XRF microscanner. Journal of Sedimentary Research 3-5, 824-829.

Lalou C. (1985) - Les méthodes de datation par les déséquilibres dans les familles de l'uranium. In Roth. E, Poty B. (Eds.): Méthodes de datation par les phénomènes nucléaires naturels, applications. Masson, Collection CEA, Paris, 175-201.

Lans B., Maire R., Ortega R., Devès G., Bacquart T., Plaisir C., Quinif Y., Perrette Y. (2006) - Les stalagmites du réseau du Trou Noir (Gironde): rôle de l'effet de site dans l'enregistrement du signal climatique et environnemental. Karstologia, 48, 1-22. 
Maire R. (1990) - La haute montagne calcaire: karsts, cavités, remplissages, Quaternaire, paléoclimats. Thèse d'État, université de Nice, Karstologia Mémoires, 3, 730 p.

Maire R. (1991) - Les remplissages karstiques. In Barbary J.-P., Maire R., Zhang S. (Eds.) : Gebihe 89, karsts de Chine. Karstologia Mémoires, 4, chap. 9, 132-149.

Maire R., Pomel S., Salomon J.-N. (Eds.) (1994) - Enregistreurs et indicateurs de l'évolution de l'environnement en zone tropicale. PUB, collection «Espaces Tropicaux » 13, CEGET-LGPA, 492 p.

Maire R., Devès G., Perroux A.-S, Lans B., Bacquart T., Plaisir C., Ortega R. (2009a) - Uranium mapping in speleothems: occurrence of diagenesis, detrital contamination, and geochemical consequences. In White B.W. (Ed.): Proceedings of 15th International Congress of Speleology. Kerrville, Texas, 1033-1038.

Maire R., Douat M., Quinif Y., Varrel E. (2009b) - Le karst de la Pierre Saint-Martin. Un patrimoine unique pour la science. In Vanara N., Douat M. (Eds.) : Le karst, indicateur performant des environnements passés et actuels. Karstologia Mémoires, 17, 16-31.

Maire R., Tourte B., Jaillet S., Despain J., Lans B., Brehier F., Fage L.H., Morel L., Pouilly M., Datry T., Massault M., Genty D., Wainer K., Ridoux V., Dabin W., Pernette J.-F., Agüero Faridoni M., Manneschi M.J. and Teams of Ultima Patagonia Expeditions (2009c) - Geomorphic and archeological features of coastal caves in Madre de Dios archipelago (Patagonia, Chile). In White B.W. (Ed.): Proceedings of 15th International Congress of Speleology. Kerrville, Texas, 516-521.

Maire R., Valla F., Lamboglia C., Lamboglia J., Lochey M., Boscart J., Decker J., Siffre M., Michaux M., Caillault S., Morel L. (2009d) - Chronique d'une disparition annoncée (Alpes-Maritimes) : le gouffre de Scarasson. Spéléo Magazine, 68, 18-21.

Ortega R., Devès G., Maire R. (2003) - Nuclear microprobe analysis of uranium-rich speleothems: methodological aspects. $\mathrm{Nu}$ clear Instruments and Methods B 210, 455-458.

Ortega R., Maire R., Devès G., Quinif Y. (2005) - High-resolution mapping of uranium and other trace elements in recrystallized aragonite-calcite speleothems from caves in the Pyrenees (France) : Implication for U-series dating. Earth and Planetary Science Letters 237, 911-923.

Ortega R., Devès G., Baquart T., Plaisir C., Perroux A.-S., Maire R. (2010) - Imagerie quantitative microchimique des élé- ments inorganiques dans les spéléothèmes. In Vanara N., Douat M. (Eds.) : Le karst, indicateur performant des environnements passés et actuels. Karstologia Mémoires, 17, 83-87.

Perroux A.-S., Ortega R., Devès G., Maire R. (2010) - Apports des données nouvelles sur les remplissages détritiques souterrains étudiés en tant qu'archive environnementale: les analyses par microsonde XRF. In Vanara N., Douat M. (Eds.) : Le karst, indicateur performant des environnements passés et actuels. Karstologia Mémoires, 17, 76-82.

Peterson L.C., Haug G.H., Hughen K.A., Röhl U. (2000) Rapid Changes in the Hydrologic Cycle of the Tropical Atlantic During the Last Glacial. Science 290, 1947-1951.

Pomel S., Maire R. (1995) - Relations entre les remplissages souterrains et la déstabilisation de l'environnement. In Barbary J.-P., Maire R., Zhang S., Pomel S., Collignon B. (Eds.) : Donghe 92, karsts de Chine centrale. Karstologia mémoires, 6, chap. 6, 101-120.

Pomel S., Maire R. (1997) - Exemple d'enregistrement des changements climatiques et de l'anthropisation dans les remplissages endokarstiques de Chine centrale (Hubei). Quaternaire 8, 119-128.

Renault P. (1990) - Réflexions sur la notion de remplissages karstiques. In Lalou J.-C. (Ed.) : Remplissages karstiques et paléoclimats. Karstologia Mémoires, 2, 61-62.

Richter T.O., Van der Gaast S., Koster B., Vaars A., Gieles R., De Stigter H.C., De Haas H., Van Weering T.C.E. (2006) The Avaatech XRF Core Scanner: technical description and applications to NE Atlantic sediments. In Rothwell R.G. (Ed.): New Techniques in Sediment Core Analysis. Geological Society, London, Special Publication, 267, 39-50.

Siklosy Z., Demeny A, Vennemann T.W., Pilet S., Kramers J., Leel-Össy S., Bondar M., Shen C.-C., Hegner E. (2009) Bronze Age volcanic event recorded in stalagmites by combined isotope and trace element studies. Rapid Communication Mass Spectrometry 23, 801-808.

Vanara N., Douat M. (Eds.) (2010) - Le karst, indicateur performant des environnements passés et actuels. Karstologia Mémoires, 17, $243 \mathrm{p}$.

White W.B. (2007) - Cave sediments and paleoclimate. Journal of Cave and Karst studies 69-1, 76-93.

Article soumis le 11 août 2010, accepté le 3 janvier 2011. 